Acta Bot. Croat. 71 (2), 311-363, 2012

\title{
Centric diatoms of large rivers and tributaries in Hungary: morphology and biogeographic distribution
}

\author{
Keve T. KISS ${ }^{1 *}$, Rolf $\mathrm{KLEE}^{2}$, LuC ECTOR ${ }^{3}$, Éva ÁCs ${ }^{1}$ \\ ${ }^{1}$ Danube Research Institute, Centre for Ecological Research of Hungarian Academy \\ of Science, H-2131 Göd, Jávorka S. u. 14, Hungary \\ ${ }^{2}$ Pähler Str. 8, D-82346 Andechs, Germany \\ ${ }^{3}$ Public Research Centre - Gabriel Lippmann, Department of Environment and \\ Agro-biotechnologies (EVA), 41 rue du Brill, L-4422 Belvaux, Luxembourg
}

Centric diatoms of 107 different Hungarian running waters were investigated. Among them the largest was the River Danube, from which more than one hundred plankton samples were analysed by scanning electron microscopy (SEM). Only one sample was analysed from creeks, which were the smallest running waters analysed in this study. There were also channels with slow currents flowing out of rivers or connecting different rivers. In total, 41 centric taxa belonging to 11 genera were found during this study. The average number of taxa found in a single watercourse was 7 , the maximum 40 and the minimum 1 . Cyclotella meneghiniana was the most frequently encountered species (present in $60 \%$ of sites). Twelve taxa were found in more than $20 \%$ of sites, 7 taxa between $5-10 \%$ and 6 taxa only in one site.

Key words: diatoms, diversity, distribution, Actinocyclus, Aulacoseira, Conticribra, Cyclostephanos, Cyclotella, Discostella, Melosira, Skeletonema, Stephanocostis, Stephanodiscus, Thalassiosira, Hungary

\section{Introduction}

The presence of centric diatoms is characteristic of European lakes especially in spring, but they are also dominant and frequently abundant in large, slowly flowing rivers from early spring to autumn. Therefore, this is an important group of primary producers and water quality indicators.

The European Union Water Framework Directive (WFD) requires that the ecological status of water bodies in member states should be examined, and that a good ecological

* Corresponding author, e-mail: kiss.keve@okologia.mta.hu

Copyright $^{\circledR} 2012$ by Acta Botanica Croatica, the Faculty of Science, University of Zagreb. All rights reserved. 
status should be attained by 2015 . According to WFD, among other mandatory actions, it is obligatory to investigate phytoplankton and periphyton communities. Typically, several centric diatom taxa can be found in such samples, often reaching huge abundances and they should therefore be identified at species level.

Diatoms are effective tools for the assessment of the ecological status of wetland habitats as well. The occurrence of species with declining populations in a given habitat is characteristic of vulnerable areas. The reason for such decline is generally the decreasing diversity of habitats (e.g., as a consequence of eutrophication of water) or the decreasing number of optimal habitats. The occurrence of diminishing and presumably endangered species in the water is important from floristic and conservation respects since they can serve as a reason for a given area to be protected. The establishment of a Red List is also important for microscopic organisms (LANGE-BERTALOT and STEINDORF 1996). Among the centric diatoms we can also find some rare (e.g., Orthoseira roseana) and some alien or potentially invasive species (e.g., Actinocyclus normanii, Cyclostephanos delicatus, Skeletonema potamos, Thalassiosira gessneri) (KISS et al. 2002, KAŠTOVSKÝ et al. 2010), so their study is also important from the point of view of conservation.

The diatom flora of the River Danube is well studied (KISs 1984, 1986, 1987, 1988, 2005, KISS and NAusch 1988, Kiss et al. 1990, Kiss and GENKAL 1993, 1996, Ács et al. 2006), while there have been only a few electron microscopic examinations of the centric diatoms of other Hungarian rivers. The revision of previous light microscopic investigations (SzEMES 1967, UHERKOVICH 1971) was necessary in order to compare these with the results obtained with the electron microscopic analyses by KIss (1986). These two factors motivated us to summarize the most recent data about the centric diatoms of the Hungarian stretches of the rivers Danube and Tisza and their tributaries.

The aim of this work was to study the species composition and biodiversity of centric diatoms in Hungarian water flows. A 4-year grant was received to study the centric diatoms in the Eastern part of Hungary; therefore, we examined more samples from this region than from the Western part of the country. A few hundred samples were collected from more than 100 water bodies of the Hungarian watershed area of the River Danube and the River Tisza (including tributaries, channels, backwaters and side arms). The morphology and biogeographic distribution of 41 taxa are presented here. In the case of rare or less widespread species (like Conticribra guillardii, Thalassiosira duostra, Cyclostephanos delicatus, Cyclotella balatonis, $C$. choctawhatcheeana, etc.) the recent literature is cited, in other cases (like Melosira varians, Aulacoseira granulata, Conticribra weissflogii, Cyclostephanos dubius, etc), only the most important references.

\section{Materials and methods}

More than twenty large Hungarian rivers (Berettyó, Bodrog, Bódva, Danube, Dráva, Hármas-Körös, Hernád, Hortobágy, Ipoly, Kettös-Körös, Kraszna, Marcal, Maros, Rába, Sajó, Sebes-Körös, Szamos, Tarna, Tisza, Túr, Zagyva) and their tributaries, related channels, backwaters and side arms (altogether 107 different Hungarian running waters) were examined (Fig. 1A). The mean water discharge of the large rivers has a wide range (the largest, the River Danube, has a discharge of $2300 \mathrm{~m}^{3} \mathrm{~s}^{-1}$ and the smallest streams of $\sim 5 \mathrm{~m}^{3} \mathrm{~s}^{-1}$ ). Channels flowing out of rivers or connecting different rivers were also investigated; usually 
they are slowly flowing channels of different sizes (discharges between $0.1-1 \mathrm{~m}^{3} \mathrm{~s}^{-1}$ and $10-40 \mathrm{~m}^{3} \mathrm{~s}^{-1}$ ).

Samples were taken 1-3 times for the great majority of these running water ecosystems. If a sample was free from centric diatoms the sampling was repeated later. Among the largest rivers like Danube and Tisza rivers several tens of samples were taken and the diatoms analysed by EM. The smallest sampling sites investigated were several creeks from which only one sample was analysed.

One-litre samples were taken from the main current $20-30 \mathrm{~cm}$ below the water surface and preserved with formaldehyde. Samples were treated with hydrochloric acid and hydrogen peroxide, washed several times with distilled water and coated with gold-palladium for SEM investigations. The micrographs were taken with a HITACHI S-2600-N scanning electron microscope in digital form.

Data of valve size (diameter, number of striae/10 $\mu \mathrm{m}$, etc) for each taxa are integrated from our own measurements and from literature data. The structural elements of the valves were measured and analysed on the basis of the terminology provided by GENKAL (1977), which is in accordance with ANONYMOus (1975), Ross et al. (1979) and THERIOT and SERIEYSSOL (1994).

The taxonomic part of the paper is mostly based on the traditional classification system of Round et al. (1990), but some newly described genera were also added (e.g., Conticribra, Discostella).

The species distribution is shown on a sketch map of Hungary prepared using the ESRI ArcInfo 9.3 GIS program (Fig. 1A); the small, 1-4 order, streams are not drawn on the map. Sampling site coordinates and detailed occurrence data of species are available upon request to the first author.

\section{Results}

The morphological and ecological characteristics, as well as distributional data of the 41 centric diatom taxa found in Hungarian watercourses are presented below. The morphological characterization of each taxon is complemented with EM micrographs and distribution maps. Our long term experience and the Hungarian database (http://okir.kvvm.hu/fevi/) were used to characterise several ecological preferences of a given taxon.

\section{COSCINODISCOPHYCEAE MELOSIRALES}

\section{$\underline{\text { Melosiraceae }}$}

Melosira C. Agardh 1827

Melosira varians C. Agardh 1827 (Figs. 1 B-E)

The frustules of Melosira varians are cylindrical and form chains $(8-35 \mu \mathrm{m}$ in diameter). Chains can be long (even 300-500 $\mu \mathrm{m}$ or more in the periphyton, but can be short or »unicellular chains « in the plankton of rivers). Valve mantles are finely punctuated with irregularly arranged openings of rimoportulae. The girdle band comprises a few copulae (Fig. 1 B). Valve face is flat and regularly finely punctuated (Fig. 1. C, D) with small 


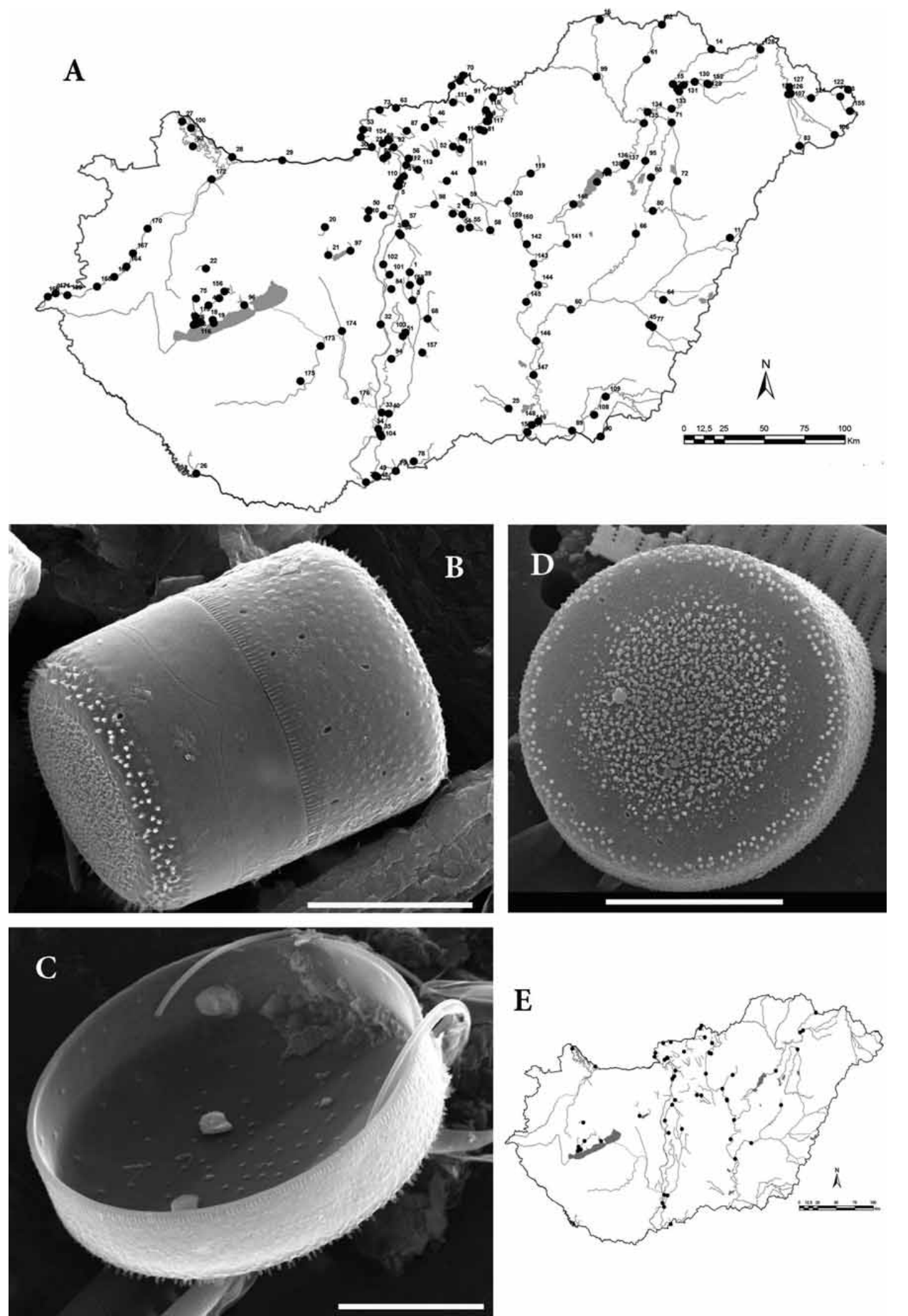

Fig. 1. A - Sampling sites (positions available upon request). B-D - Melosira varians in girdle-, inside-, outside view. E - Distribution of $M$. varians. Scale bar $10 \mu \mathrm{m}$. 
granules in the central part (Fig. 1 D). Near the margin, short, thin connecting spinulae can be seen by SEM (Figs. $1 \mathrm{~B}, \mathrm{C}$ ).

Melosira varians is a cosmopolitan species that occurs both in benthos and plankton. It can be found in dystrophic and oligotrophic to eutrophic waters. It is frequent in Hungarian running waters with a $36 \%$ occurrence rate (Fig. 1 E).

\section{AULACOSEIRALES}

\section{$\underline{\text { Aulacosiraceae }}$}

Aulacoseira Thwaites 1848

\section{Aulacoseira ambigua (Grunow) Simonsen 1979 (Figs. 2 A-C)}

Aulacoseira ambigua was first illustrated in VAN HEURCK (1882) as a variety of Melosira crenulata. In 1903, MüLLER proposed the separation of this taxon from the base species, using the name M. ambigua. Later on, SimONSEN $(1979$, p. 56) transferred M. ambigua to the genus Aulacoseira. Important new results are summarised about Melosira and Aulacoseira species in the papers of HouK (2003, Tab. 16) and HouK and KLEE (2007).

The cylindrical frustules form long chains. Cell sizes: diameter 4-17 $\mu \mathrm{m}$ and mantle length $3.5-15.0 \mu \mathrm{m}$. The areolae are more or less round or elongated, arranged in spiral rows, running dextrorse on the mantle, 24-26 rows in $10 \mu \mathrm{m}$. The row of areolae always begins between each spine (Fig. 2. A). The spines of the separation cells are simple, conical and those of the linking cells are small, spatulate (Fig. 2 B). The valve face is flat, with randomly arranged pores at the margin. The collar is medium high. The hollow ringleist (pseudoseptum) is semicircular; its external opening is well visible on the mantle.

Aulacoseira ambigua is cosmopolitan, widely distributed in the plankton of mesotrophic/eutrophic lakes and slow running rivers. It has a medium frequency in Hungarian running waters with a $14 \%$ occurrence rate (Fig. 2 C).

Aulacoseira granulata (Ehrenberg) Simonsen 1979 (Figs. 2 D-F)

EHRENBERG described this species in 1843 as Gallionella granulata. RALFS in PRITCHARD et al. (1861: 815-820) transferred the taxon to the genus Melosira and SimONSEN (1979) to Aulacoseira.

Frustules are cylindrical, in long straight chains, diameter 3-30 $\mu \mathrm{m}$, mantle length 4-24 $\mathrm{mm}$. The rows of coarse areolae on the valve mantle of the separation valves are arranged parallel to the pervalvar axis, $7-15$ rows in $10 \mu \mathrm{m}$ (Fig. $2 \mathrm{D})$. In contrast, the linking valves have dextrorse rows of areolae (Fig. 2 E). Areolae can vary in shape (round, oval, nearly square) even on different valves of one chain. There are short, cone-shaped spines at the margin of the valve face. Characteristic long spines (2-4) are situated in the furrows of the next separation valve (Fig. 2 D). There are linking valves with short, spatulate or flared spines. The valve face is flat with irregular pores near the margin, absent in the centre. The collar is short, the ringleist is almost undeveloped.

Aulacoseira granulata is a cosmopolitan species occurring in eutrophic rivers, ponds and lakes. It has a medium frequency in Hungarian running waters with a $20 \%$ occurrence rate (Fig. 2 F). 
Kiss K. T., KleE R., Ector L., Ács É.
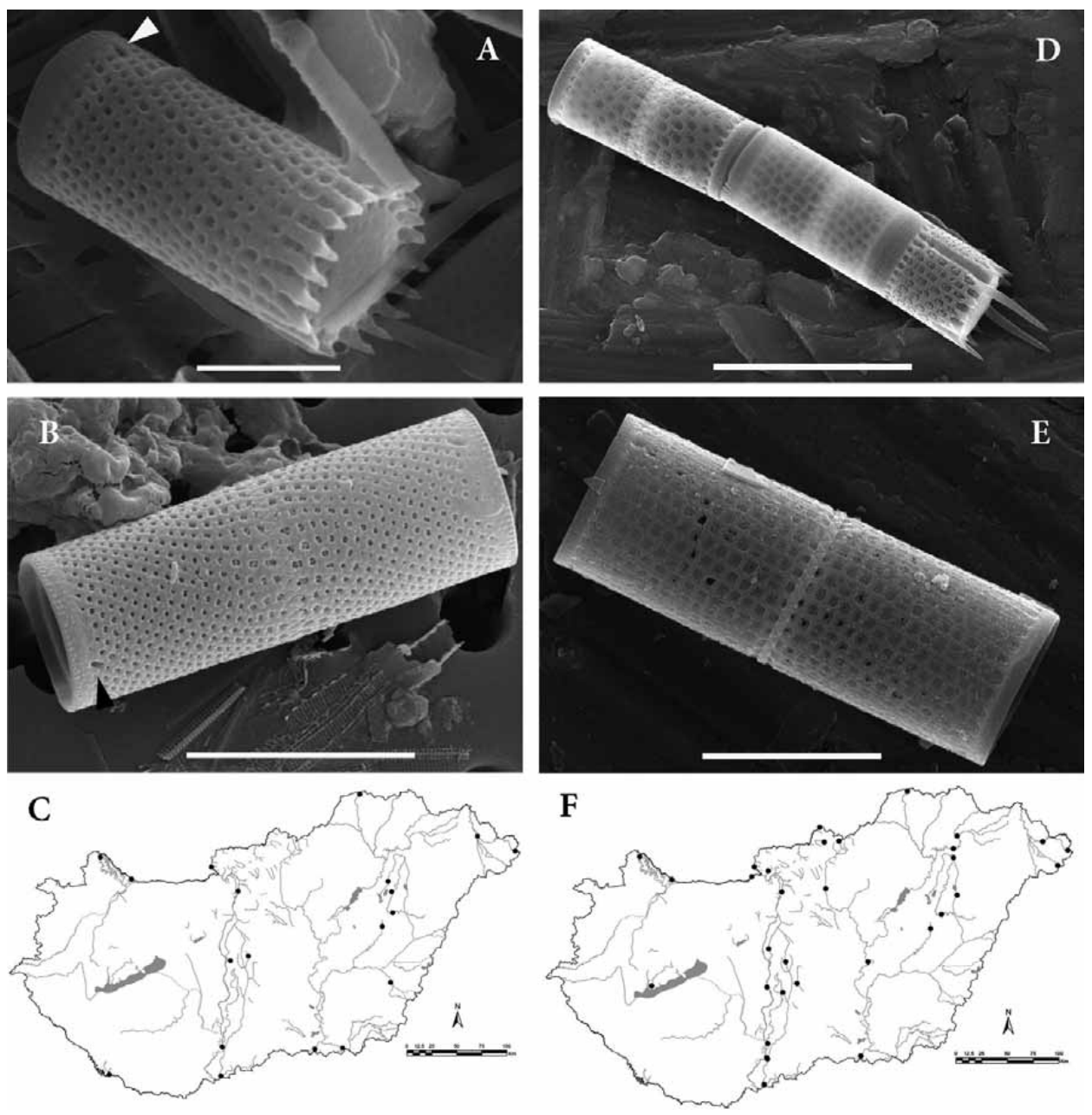

Fig. 2. A-B - Aulacoseira ambigua outside view and girdle view (external opening or tube of rimoportula or internally the rimoportula with arrowhead on all micrographs where it is seen). D Chain; $\mathrm{E}$ - girdle view of A. granulata: $\mathrm{C}$ - distribution of A. ambigua: $\mathrm{F}$ - A. granulata. Scale bar $20 \mu \mathrm{m}$ (D), $10 \mu \mathrm{m}$ (B, E) and $5 \mu \mathrm{m}$ (A).

Aulacoseira italica (Ehrenberg) Simonsen 1979 emend. R.M. Crawford, Likoshway et R. Jahn 2003 (Figs. 3 A-C)

EHRENBERG (1838) described this species as Gallionella italica from fossil diatomite from Santa Fiora, Tuscany, Italy, collected by KLAPROTH (CRAWFORD et al. 2003). Later, it was transferred to the genus Melosira as M. italica (Ehrenberg) Kützing (KüTzING 1844) and to Aulacoseira by SIMONSEN (1979). Finally, CRAWFORD et al. (2003) described and illustrated in detail the type material of Santa Fiora.

Frustules are cylindrical, forming long straight chains with a diameter of 3-30 $\mu \mathrm{m}$ and a mantle length of $8-20 \mu \mathrm{m}$. Valve face flat to slightly convex with small, irregularly arranged 

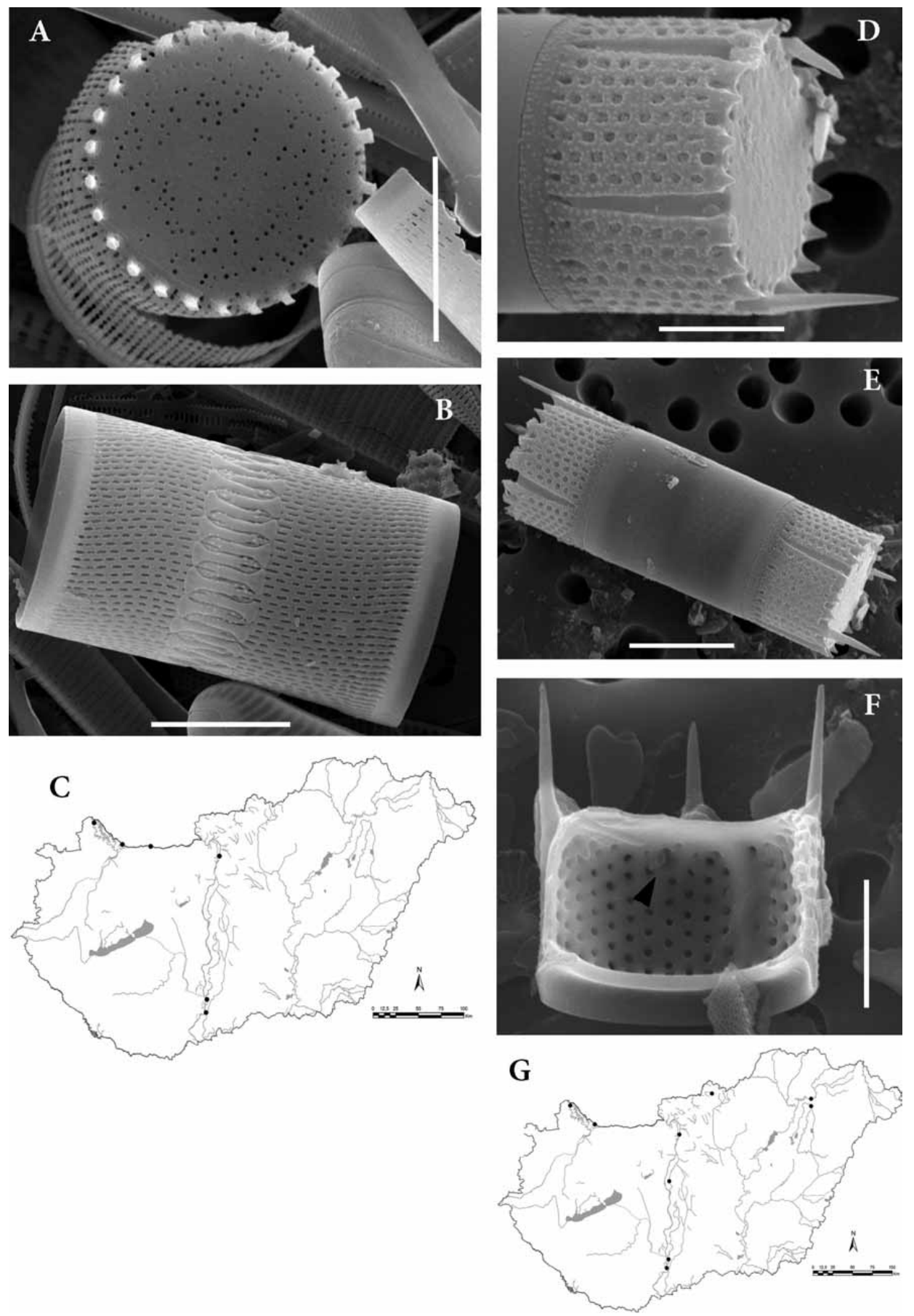

Fig. 3. A-B - Aulacoseira italica outside and girdle view. D-F - A. aff. muzzanensis outside view, chain and inside view; $\mathrm{C}$ - distribution of A. italica; $\mathrm{G}-A$. aff. muzzanensis. Scale bar $10 \mu \mathrm{m}$ $(\mathrm{A}, \mathrm{B}, \mathrm{E})$ and $5 \mu \mathrm{m}(\mathrm{D}, \mathrm{F})$. 
pores (Fig. 3 A). Rows of mostly fine, pervalvar elongated areolae on the valve mantle, arranged parallel or slightly curved to the pervalvar axis (sinistrorse), 3-18 rows in $10 \mu \mathrm{m}$. Linking spines are robust and relatively long, spatulate and often jagged at the tips; spines of the sibling valves are interconnected (Fig. 3 B). The long conical, pointed separating spines are situated in a thin ring. The collar is medium high; the ringleist is almost absent. Girdles composed by several slight girdle bands.

Aulacoseira italica is a cosmopolitan species in eutrophic rivers, ponds and lakes. It is a rare species in Hungarian running waters with a $1 \%$ occurrence rate (Fig. 3 C).

\section{Aulacoseira aff. muzzanensis (F. Meister) Krammer 1991 (Figs. 3 D-G)}

MEISTER (1912) described the species as Melosira muzzanensis but it was transferred in 1991 to the genus Aulacoseira by KRAMMER, who illustrated the isotype from a lake in Switzerland, Lago di Muzzano (KRAMMER 1991). The specimens found in Hungary correspond well to the illustrations given by Houk (2003, pl. 27, Figs. 1-7), Aulacoseira aff. muzzanensis (F. Meister) Krammer, for populations of South Moravia and Bohemia.

Frustules cylindrical, forming short chains with connection of valves and long acute connection spines, but frequently occurring in a double cell form, too (Fig. $3 \mathrm{E}$ ). Diameter is 8-25 $\mu \mathrm{m}$, mantle length 4-8 $\mu \mathrm{m}$. The more or less straight rows of coarse, mainly rectangular, areolae on the valve mantle are arranged parallel to the pervalvar axis, 7-10 rows in $10 \mu \mathrm{m}$ (Fig. $3 \mathrm{D}-\mathrm{F})$. There is one row of areolae below each spine and one row of areolae between each spine. Separating valves have cone-shaped spines at the margin of the valve face, different in length. Characteristic long spines (2-4) are situated in the furrows of the next separation valve (Fig. 3 E). Linking valves are with short, spatulate or bifurcated spines, originating from each interstria. The valve face is flat with marginally dispersed fine areolae on the discus. The collar is short; the ringleist is almost absent. The rimoportulae are close to the valve face (Fig. $3 \mathrm{~F}$ ).

Aulacoseira muzzanensis is a cosmopolitan species found in plankton and benthos, also in mesotrophic/eutrophic rivers, ponds and lakes. It is rare in Hungarian running waters with a $5 \%$ occurrence rate (Fig. $3 \mathrm{G}$ ).

\section{Aulacoseira pusilla (F. Meister) Tuji et Houki 2004 (Figs. 4 A, B, E)}

Melosira pusilla was described by MEISTER (1913) from Lake Suwa (Nagano Prefecture, Japan). TuJI and Houki (2004) proposed a new combination, Aulacoseira pusilla, and TuJI and Williams (2006) claimed that Aulacoseira subborealis (Nygaard) Denys, Muylaert et Krammer (DENYs et al. 2003) is a synonym of this taxon.

The frustules are cylindrical, in short chains, frequently in a double cell form (Fig. 4 B). Cell sizes: $5.5-9.0 \mu \mathrm{m}$ in diameter (mostly 6-7 $\mu \mathrm{m}$ ) and 2-4 $\mu \mathrm{m}$ in mantle length. The more or less round areolae on the mantle are generally somewhat inclined (sinistrorse and up to ca. $20^{\circ}$ ) and curved but may sometimes be almost straight and parallel to the pervalvar axis (Fig. 4 B). The spines are rather small and simple, pointed, without anchors or projections. The number of pervalvar ribs at the spine base is 2 . Mantle areolae $28-38 / 10 \mu \mathrm{m}$; pervalvar striae $23-28 / 10 \mu \mathrm{m}$. Areolae on the valve face are spread over the entire surface or a broad marginal zone (Fig. 4 A). The rimoportula is situated at the base of a row of areolae on the inner side of the pseudoseptum. Its external opening is inconspicuous and probably represented by or associated with an areola. The collar is short and the ringleist is almost absent. 

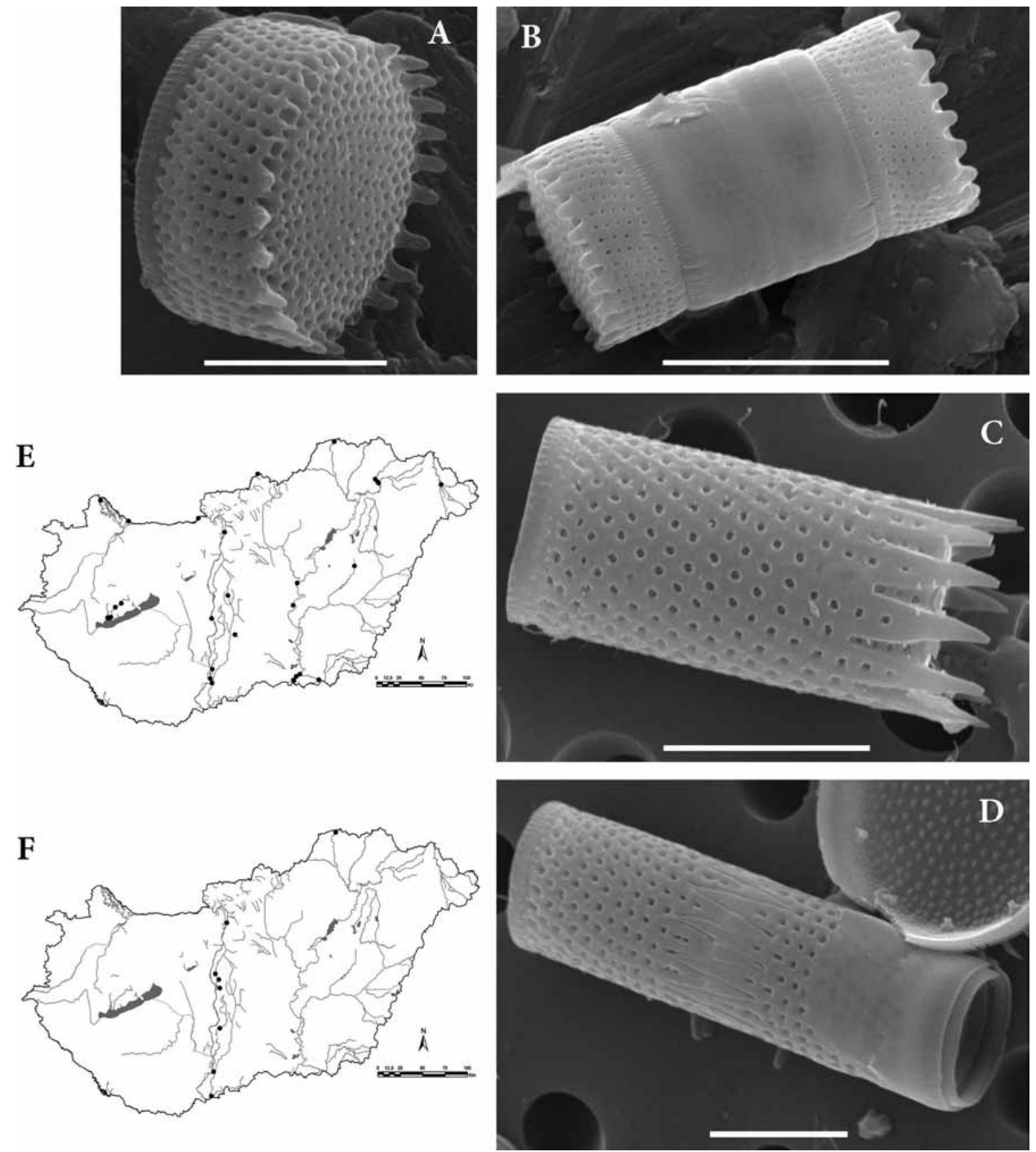

Fig. 4. A-B -Aulacoseira pusilla outside and girdle view. C-D - A. subarctica outside and girdle view; $\mathrm{E}$ - distribution of A. pusilla; F-A. subarctica. Scale bar $10 \mu \mathrm{m}$ (B) and $5 \mu \mathrm{m}$ (A, C, D).

Aulacoseira pusilla is cosmopolitan, can be found in the plankton of rivers and also in lakes. It has a medium frequency in Hungarian running waters, with a $14 \%$ occurrence rate (Fig. 4 E).

Aulacoseira subarctica (O. Müller) E.Y. Haworth 1990 (Figs. 4 C, D, F)

The species was described by MüLLER (1906) as Melosira italica subsp. subarctica and the type material has been investigated and illustrated by TUJ and Houki (2004). SiMONSEN (1979) transferred the taxon to the Aulacoseira genus. HAWORTH (1988) named it A. subarctica as a separate species and validated this new name later (HAWORTH 1990). 
Frustules are cylindrical, forming long chains. Cell sizes: $3-15 \mu \mathrm{m}$ in diameter and 3.5$18 \mu \mathrm{m}$ in mantle length. Areolae $12-20 / 10 \mu \mathrm{m}$ on the mantle in curved, dextrorse rows $17-21 / 10 \mu \mathrm{m}$ (Figs. $4 \mathrm{C}, \mathrm{D})$. One of the characteristic features of A. subarctica is the relatively long, strong, conical, pointed spines (Fig. 4 D). Every second row of round or slightly elongated areolae clearly begins in the spine base. The valve face is flat with randomly arranged fine pores at the valve face margin (TUJI and HoUKI 2004). The collar is low, and the ringleist is strongly developed.

Aulacoseira subarctica is a planktonic species in oligotrophic to eutrophic lakes, ponds and slowly running rivers. It is widely distributed across Northern Europe, North America, Japan, China, Australia and New Zealand but rare in the tropics (GIBSON et al. 2003). It is a scarce species in Hungarian running waters with a $7 \%$ occurrence rate (Fig. 4 F).

\section{THALASSIOSIRALES}

\section{Thalassiosiraceae}

Conticribra Stachura-Suchoples et D.M. Williams 2009

Conticribra guillardii (Hasle) Stachura-Suchoples et D.M. Williams 2009 (Figs. 5 A-C)

The species was described by HASLE (1978) from a brackish water locality (Helsinki, Gulf of Finland) and was transferred to the Conticribra genus by STACHURA-SUCHOPLES and WILLIAMS (2009). Additional data were published about its morphology by MAKAROVA et al. (1979), Kiss et al. (1984), GENKAL (1992), TRIGUEROS et al. (2000).

Frustule rectangular in girdle view, diameter is $5-14 \mu \mathrm{m}$. The length of the pervalvar axis is $1 / 3$ of the diameter. Solitary cells, colonies not observed. Valve face with radial, somewhat irregular rows of pores (Fig. 5 A). The pores can form tiny areolae on the valve margin. A fine siliceous ring irregular in shape can be located in the centre of the valve face from which slightly elevated, repeatedly dichotomously branched interfascicles extend towards the valve margin. Their number on the valve face is $3-5$ in $1 \mu \mathrm{m}$, near the valve mantle $7-8$ in $1 \mu \mathrm{m}$. Valve mantle with pores and very thin striae. In some specimens, a single valve face fultoportula with three satellite pores is located at $1 / 3$ radius from valve centre on the side opposite to the rimoportula. On the valve margin, a regular ring of fultoportulae is visible $6-10$ in $10 \mu \mathrm{m}$. The marginal fultoportulae internally are surrounded by 4 satellite pores. A single rimoportula is situated on valve margin, the orientation of labium varies (Fig. 5 B). Its external tube is longer than those of the marginal fultoportulae.

Conticribra guillardii occurs in both fresh and brackish waters. It is scarce in Hungarian running waters with a $7 \%$ occurrence rate (Fig. $5 \mathrm{C}$ ).

\section{Conticribra weissflogii (Grunow) Stachura-Suchoples et D.M. Williams (Figs. 5 D-F)}

The first valid description of this species was given in VAN HEURCK (1885) as Micropodiscus weissflogii Grunow in VAN HEURCK 1885 and this taxon was illustrated later by VAN HEURCK (1896). HustedT (1926) described the same species as Thalassiosira fluviatilis. Based on LM examination of Grunow's material from Slide 416 of the Van Heurck Collection, FRYXELl and HASLE (1977) compared Micropodiscus weissflogii from Schleswig (Germany) with the material of Thalassiosira fluviatilis from the Wümme River (Hustedt Collection) and they stated that the two species are identical and proposed to synonymise both taxa making the new combination Thalassiosira weissflogii (Grunow) Fryxell et Hasle. Micropodiscus weissflogii was transferred to the new genus Conticribra by STACHURA-SuCHOPLES and WiLLIAMS (2009). 

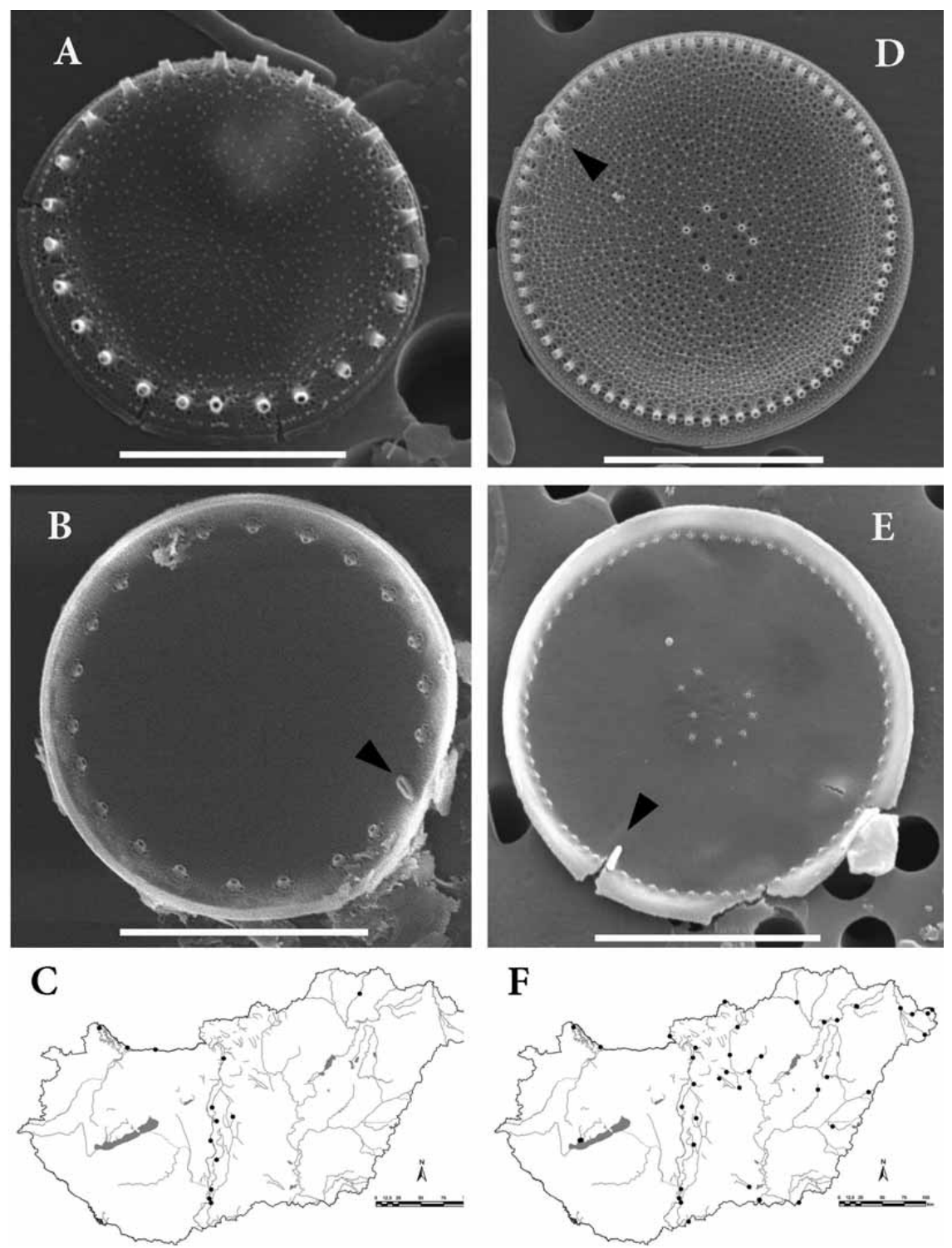

Fig. 5. A-B - Conticribra guillardii outside and inside view. D-E - C. weissflogii outside and inside view. C - distribution of C. guillardii; F - C. weissflogii. Scale bar $10 \mu \mathrm{m}(\mathrm{D}, \mathrm{E})$ and $5 \mu \mathrm{m}$ $(\mathrm{A}, \mathrm{B})$.

Frustules are drum-shaped or cylindrical, diameter $15-23 \mu \mathrm{m}$. The pervalvar axis is about half of the diameter. Valve face with radial areolation, areolae are polygonal 3-4/1 $\mu \mathrm{m}$ and $6-7 / 1 \mu \mathrm{m}$ on valve mantle. External openings of the regularly arranged marginal fultoportulae $(9-12 / 10 \mu \mathrm{m})$ with elongated tubes are situated between the valve-face and the shallow mantle; they have four satellite pores. One single, relatively large rimoportula is visible near the valve edge above the ring of the marginal fultoportulae (Fig. 5 D). Its 
external tube is longer than that of the marginal fultoportulae. The lip is usually perpendicular to the mantle (Fig. 5 E). Four to 9 or more valve-face fultoportulae with 4 (3) satellite pores are arranged in a more or less ring-like structure in the centre of the valve. The number of valve face fultoportulae increases with increasing salinity. Large valves in sea-water have more fultoportulae (10-28) than valves in brackish or freshwater (2-10).

Conticribra weissflogii is considered a cosmopolitan species. It has been recorded in polluted fresh and brackish waters, first of all rivers and streams. We consider it an euryhaline species. It is a frequent species in Hungarian running waters with a $27 \%$ occurrence rate (Fig. 5 F).

\section{Thalassiosira Cleve 1873}

Thalassiosira duostra C. Pienaar in Pienaar and Pieterse 1990 (Figs. 6 A-C)

Thalassiosira duostra was described by PIENAAR and PIETERSE (1990) from the Vaal River in South Africa. Later several new data concerning the species in Europe and South America were published (SzABó et al. 2004, Torgan et al. 2006, WoJTAL and KwANDRAnS 2006, PÉREZ et al. 2009).

The frustule is drum-shaped, with a flat valve face. Diameter varies 7-26 $\mu \mathrm{m}$ (average $14 \mu \mathrm{m}$ ); pervalvar axis 6-9 $\mu \mathrm{m}$. The valve face areolae are round (or polygonal), they can be very small or relatively large; $10-30 / 10 \mu \mathrm{m}$ (Fig. 6 A). The rows of areolae usually form 6-9 triangular sectors. There are areolae with external foramina and internal cribra. Valve mantle areolae are small, sometimes elongated, 15-40/10 $\mu \mathrm{m}$. A ring of the external tubes (0.1-1.1 $\mu \mathrm{m}$ long) of marginal fultoportulae is situated on the edge of the valve face, $8-11 / 10 \mu \mathrm{m}$ (Fig. $6 \mathrm{~A}$ ). The arrangement (position and orientation) of the tubes is not strictly regular. The internal tubes of marginal fultoportulae are very short, surrounded by four satellite pores (Fig. 6 B). Among the fultoportulae, 1-2 rimoportula are situated with well developed, radially oriented labium. The valve face fultoportulae (2-8) are situated in a different position, frequently in groups, and form a loose semicircle or are disposed on different sides of the valve face. Internally, they have 4 satellite pores. Their number can differ on the epi- and hypovalve.

Thalassiosira duostra can be characterized as a freshwater, probably mesohalobous species and has been found in several eutrophic or polluted lakes and rivers. Our data seem to confirm its wide ecological range. It has a medium frequency in Hungarian running waters with a $13 \%$ occurrence rate (Fig. 6 C).

\section{Thalassiosira gessneri Hustedt 1956 (Figs. 6 D-F)}

Thalassiosira gessneri was described by HusteDT (1956) from the Lake Maracaibo (Venezuela). HASLE and LANGE (1989), and later KISS et al. (2002) published papers about its LM and SEM morphology.

The frustules are drum shaped. The remarkable tangential undulation of the valve face is well visible in semilateral view. The diameter is $20-37 \mu \mathrm{m}$, the pervalvar axis $10-15 \mu \mathrm{m}$. The valve face areolae are small $(10-15 / 10 \mu \mathrm{m}$, Fig. 6 D), they are larger on the elevated part of the tangential undulation than on the depressed part and are covered by cribra internally (Fig. 6 E). Sometimes the valve face is smooth; the structures of the small areolae are not seen. The external pores of valve face fultoportulae are situated mainly on the elevated part of the undulation (Fig. 6 D). Internally, the valve face has a very fine striation (Fig. 6. E). The interstriae are very thin; they are cribrumless lines on the internal valve 

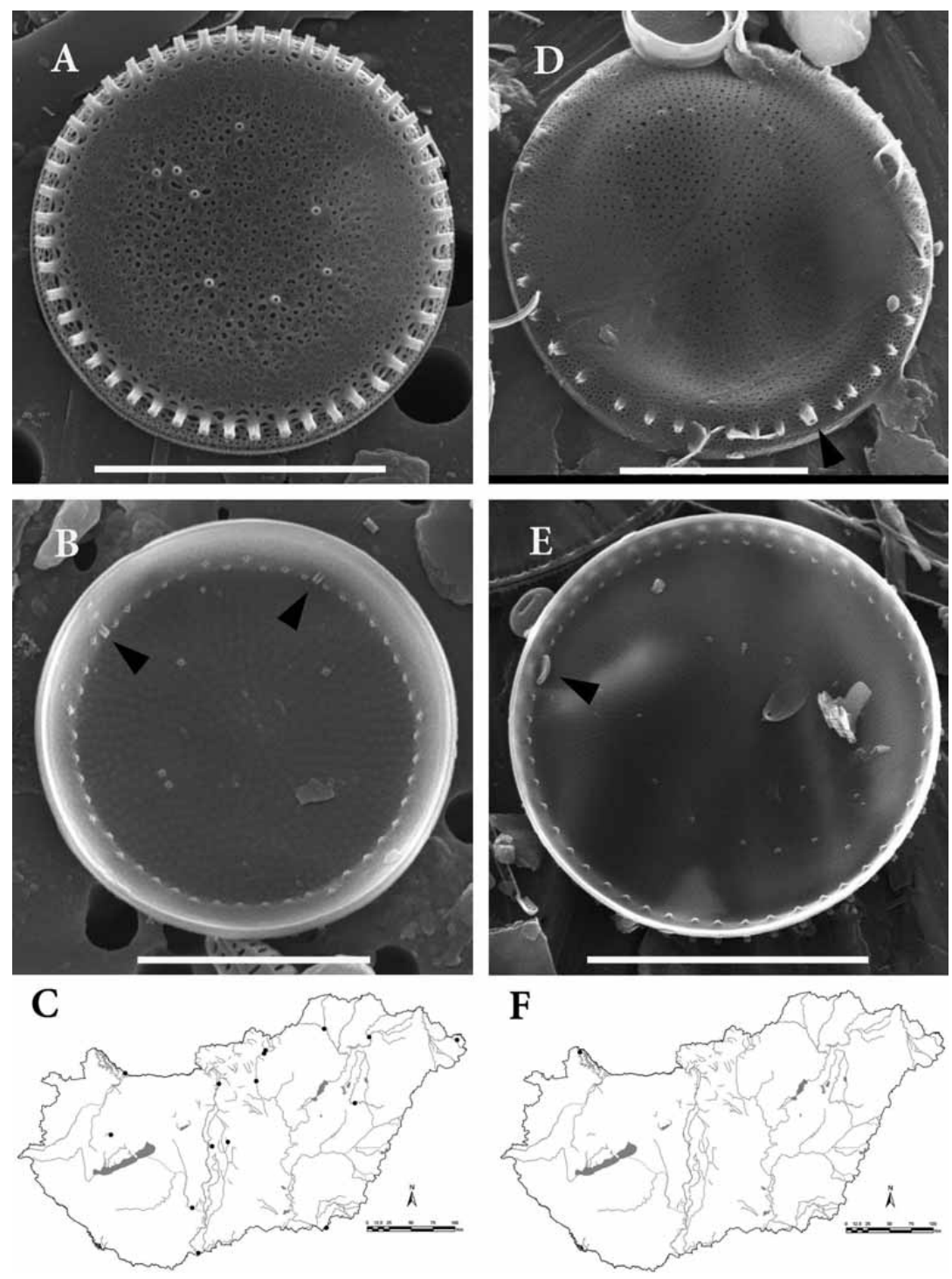

Fig. 6. A-B - Thalassiosira duostra outside and inside view. D-E - T. gessneri outside and inside view; C-distribution of T. duostra; F-T. gessneri. Scale bar: $20 \mu \mathrm{m}$ (E) and $10 \mu \mathrm{m}$ (A, B, D).

surface, radially arranged, not straight and branched. A ring of well developed fultoportulae is situated on the valve margin. Their external tube is less than $1 \mu \mathrm{m}$. The number of marginal fultoportulae is 5-7 in $10 \mu \mathrm{m}$. They are operculate and usually have five satellite pores. A single rimoportula is situated between the marginal fultoportulae. Its external tube is longer and larger than those of the fultoportulae (Fig. 6 E). The rimoportula is short-necked, differently twisted with an elongated, compressed narrow lip. The position of lip can be situated parallel, perpendicularly or in different angle to the valve mantle. The rimoportula is situated in front of the open part of the valve face fultoportulae' semicircle. 
The valve face fultoportulae have four satellite pores. The shape of the semicircular valve face fultoportulae is variable (half-ring, or more or less complete-ring). Sometimes there are additional fultoportulae inside or outside of the ring (Fig. 6. E). The number of valve face fultoportulae varies between 5-15 and increases with the diameter.

Thalassiosira gessneri can be characterized as a freshwater species, found in several eutrophic or polluted rivers in phytoplankton and periphyton samples. It is rare in Hungarian running waters with a $1 \%$ occurrence rate (Fig. $6 \mathrm{~F}$ ).

\section{Thalassiosira incerta Makarova 1961 (Figs. 7 A-C)}

Thalassiosira incerta was described by MAKAROva (1961) from the Caspian Sea and found later also in freshwater and brackish localities (HASLE 1978, BelchER and SwALE 1986, Clarke 1992).

The frustule is cylindrical, diameter $13-25 \mu \mathrm{m}$. The valve face is flat, areolae are round and relatively large (Fig. 7 A), 10-19/10 $\mu \mathrm{m}$ (small on valve mantle: 15-28/10 $\mu \mathrm{m}$ ) and covered by cribra internally (Fig. 7 B). The rows of areolae usually form 5-8 triangular sectors, interstriae are not seen. Three to 6 valve face fultoportulae are situated in the centre with three satellite pores. A ring of well developed fultoportulae is situated on the valve margin; 3-6/10 $\mu \mathrm{m}$. They are operculate and usually have five satellite pores (Fig. 7 B). A single rimoportula is situated between the marginal fultoportulae. Its external tube is longer and larger than those of the fultoportulae. The rimoportula is short-necked with an elongated, compressed narrow lip usually perpendicular to the margin.

Thalassiosira incerta was found in eutrophic fresh and brackish water lakes and rivers. It is rare in Hungarian running waters with a $2 \%$ occurrence rate (Fig. $7 \mathrm{C}$ ).

\section{Thalassiosira lacustris (Grunow) Hasle in Hasle et Fryxell 1977 (Figs. 7 D-F)}

This species was described by SMITH (1856) as Cyclotella punctata from freshwater near Wisbech. GRUNOW in CLEVE and GRUNOW (1880) transferred C. punctata to Coscinodiscus with the epithet lacustris. Later C. lacustris was transferred to Thalassiosira by HASLE and FRYXELL (1977). This species is considered an exotic and invasive diatom in North America (SMUCKER et al. 2008) and has been found in European waters of various salinities, from freshwater to brackish (HuSTEDT 1928, HASLE and LANGE 1989, Kiss et al. 2002).

Disc-shaped frustules distinctly tangentially undulated; diameter, 17-62 (70) $\mu \mathrm{m}$ (Fig. $7 \mathrm{D})$. At the base of the mantle, the valve has a marginal thickened flat rim to which the valvocopula is attached with 3-6 copulae. The coarse texture of the external valve surface formed by small or large, round or polygonal areolae is very characteristic of this taxon, 9-14 areolae/10 $\mu \mathrm{m}$. Sometimes areolae are arranged radially, sometimes their radial arrangement is not clear. The valve face fultoportulae are arranged like a ring or half-ring between the central area and the margin on the elevated part of the tangential undulation (Fig. 7 D). Sometimes there are additional fultoportulae inside or outside the ring. The number of valve face fultoportulae varies between 3 and 22. Near the margin, distinct tubular occluded processes are arranged irregularly above the ring of the marginal fultoportulae. Their external tube is about $0.5 \mu \mathrm{m}$ long. The number of marginal fultoportulae is $4-7 / 10 \mu \mathrm{m}$, and increases with the diameter of the frustule. The number of occluded processes is about half that of the marginal fultoportulae. A single rimoportula is situated above the marginal fultoportulae. Its external tube is longer and larger than that of the fultoportulae and it is found between the occluded processes. The rimoportula is short- 

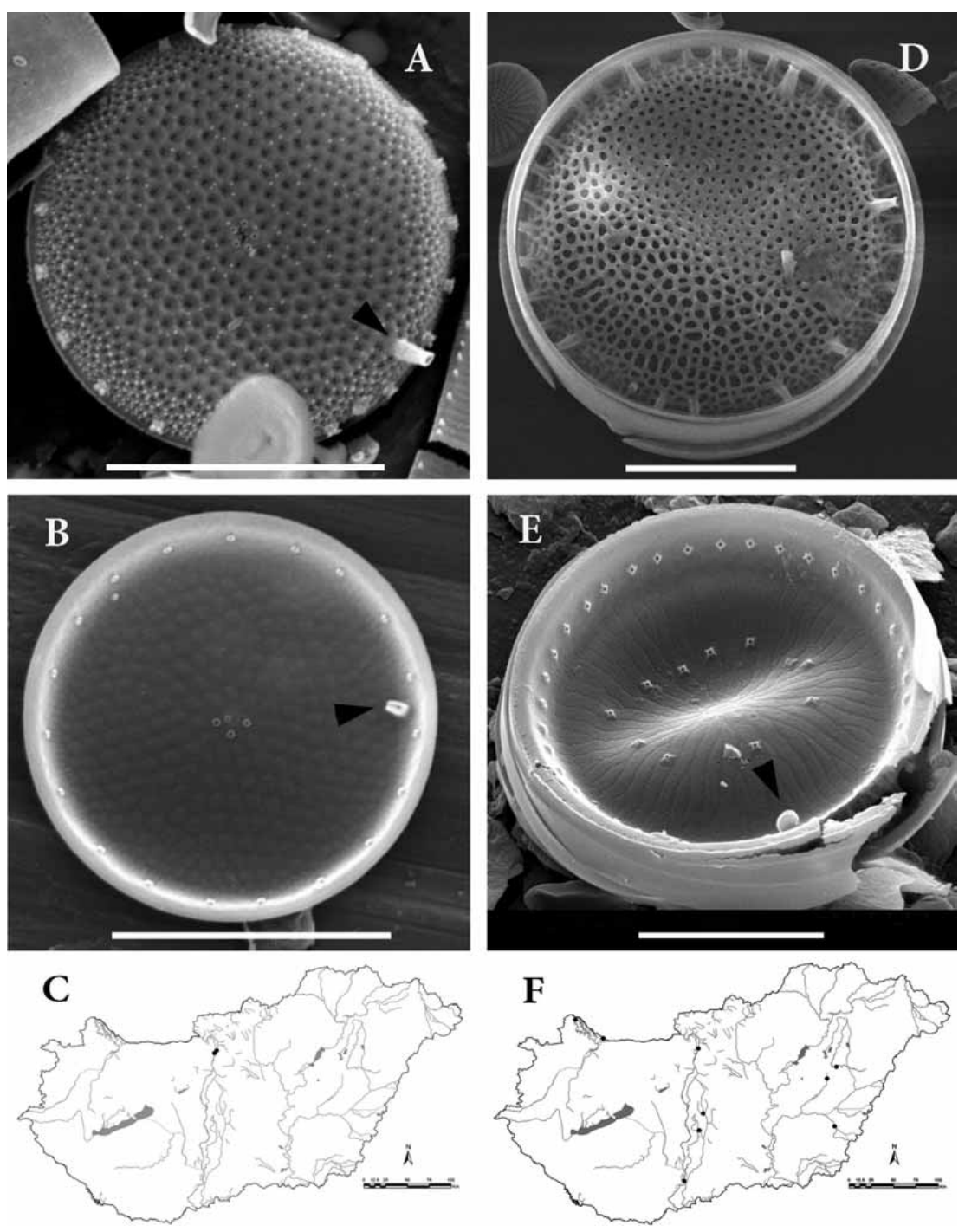

Fig. 7. A-B - Thalassiosira incerta outside and inside view. D-E - Thalassiosira lacustris outside and inside view; C - distribution of T. incerta; F - T. lacustris. Scale bar $10 \mu \mathrm{m}(\mathrm{A}, \mathrm{B}, \mathrm{D}, \mathrm{E})$.

-necked, differently twisted, with an arched, relatively large lip (Fig. 7 E). The rimoportula is situated in front of the open part of the semicircle of the valve face fultoportulae. All fultoportulae are surrounded by four satellite pores (Fig. 7 E). Internally on the valve face, very fine striation is visible. There are four-seven rows of small cribra in the striae near the margin and one-two in the centre. The interstriae are very thin, radially arranged, not straight and branched (Fig. 7 E). The edge of the valve mantle is large (thick) internally.

Thalassiosira lacustris has been recorded in fresh to brackish waters, widely distributed in lowland rivers, ponds, estuaries and coasts. It is a scarce species in Hungarian running waters with a $6 \%$ occurrence rate (Fig. 7 F). 
Kiss K. T., KleE R., Ector L., Ács É.

Thalassiosira pseudonana Hasle et Heimdal 1970 (Figs. 8 A-C)

Although described from a freshwater locality (River Wümme), this species is apparently distributed in coastal waters (HASLE and HeIMDAL 1970). Papers about its EM morphology were published by several authors: HARgraves and LEVANDOWSKY (1971), LOWE and Busch (1975), Hasle (1976), Belcher and Swale (1977), MaKarova et al. (1979), Kiss (1984). AlVERSON et al. (2011) explained well the nomenclatural history, SEM morphology and DNA structure of Thalassiosira pseudonana.
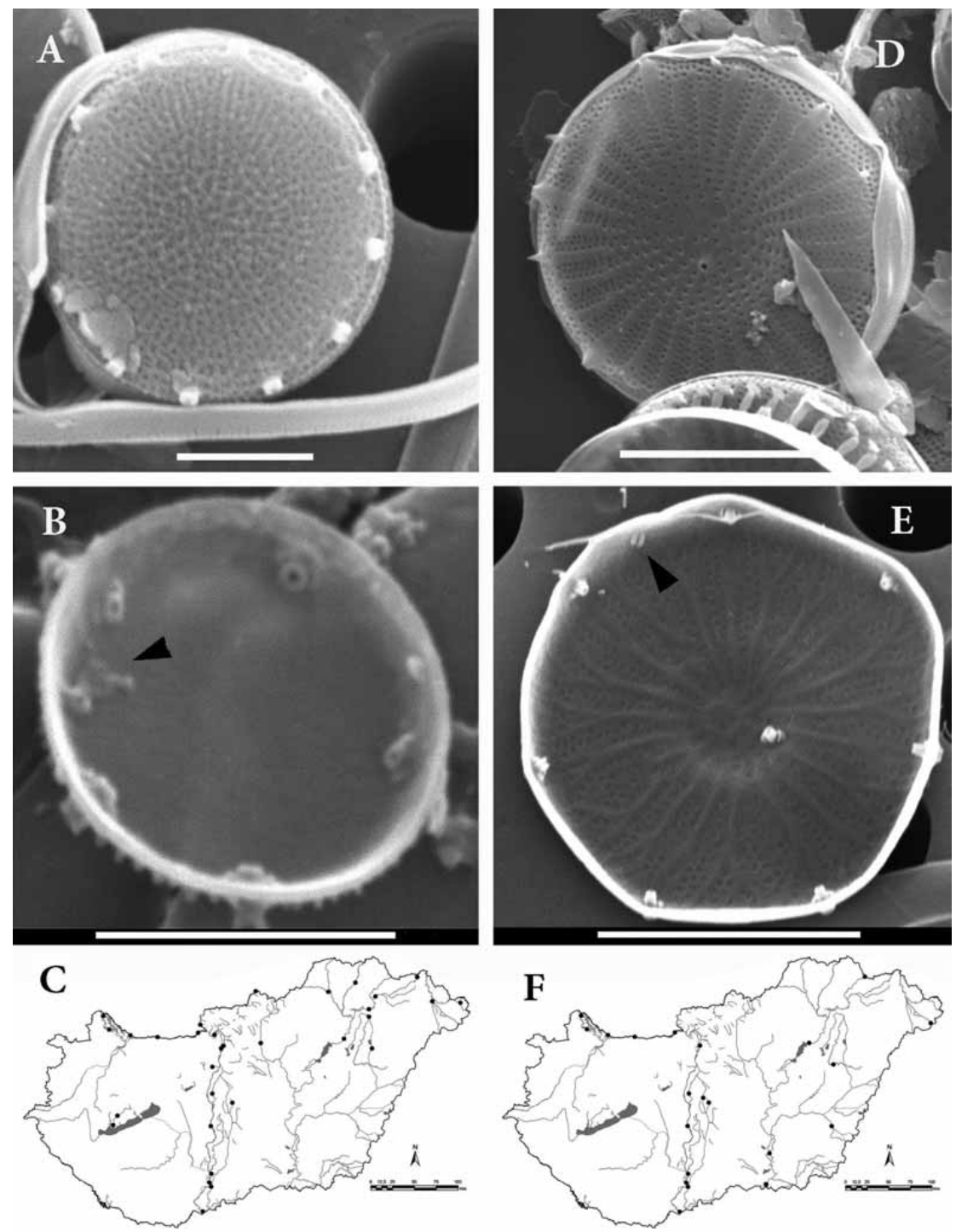

Fig. 8. A-B - Thalassiosira pseudonana outside and inside view. D-E - Cyclostephanos delicatus outside and inside view; $\mathrm{C}$ - distribution of T. pseudonana; $\mathrm{F}-C$. delicatus. Scale bar $5 \mu \mathrm{m}$ $(\mathrm{B}, \mathrm{D}, \mathrm{E})$ and $2 \mu \mathrm{m}(\mathrm{A})$. 
The frustule is cylindrical; the valve face is flat (Fig. $8 \mathrm{~A}$ ). The diameter is $2.5-9.0 \mu \mathrm{m}$, fine, and tiny pores or a polygonal areola-like structure are seen on the valve face. The exact pattern depends on the degree of silicification. Heavily silicified frustules have only fine irregular rows of pores; weakly silicified valves have a polygonal areola-like structure with interfascicles which are branched two-three times. The number of interfascicles is $2-7$ in $1 \mu \mathrm{m}$. A ring of numerous fultoportulae is seen on the valve margin with three satellite pores. Slightly below the fultoportulae a small rimoportula is found (Fig. 8 B). Rarely, a single valve face fultoportula can be observed, especially on specimens from brackish water.

Thalassiosira pseudonana has been recorded from many fresh, brackish and marine water habitats; it seems to be a euryhaline species. Sometimes it is abundant in the phytoplankton of the Danube. It has a medium frequency in Hungarian running waters with a $16 \%$ occurrence rate (Fig. $8 \mathrm{C}$ ).

\section{$\underline{\text { Skeletonemataceae }}$}

Skeletonema Greville 1865

Skeletonema potamos (C. I. Weber) Hasle in Hasle and Evensen 1976 (Figs. 9 A-C)

The species was described as Stephanodiscus subsalsus (Cleve-Euler) Hustedt from Lake Jensen in Germany (HUSTEDT 1928). A second description was published from freshwater habitats by WEBER (1970) under the new genus and species name Microsiphona potamos Weber. HASLE and EVENSEN (1976) established the correct taxonomical position of the species with the new combination Skeletonema potamos.

Cell diameter is 3.0-6.5 $\mu \mathrm{m}$, length of pervalvar axis varies between 5-18 $\mu \mathrm{m}$. The valve face is flat in the centre and slightly rounded near the valve mantle (Fig. 9 A). There are fine radial striae on the valve face, consisting of irregular polygonal »areolae « and two-three times branched interfascicles (very thin rib-like structure). Near the margin, a ring of 3-8 fultoportulae is situated. The fultoportulae are tubular, cleft at the distal tip. They are »thick-walled « like the valve face with the rib-like elevations extending from the valve surface onto the fultoportulae. A single rimoportula is visible between the marginal fultoportulae. It is situated in the middle of the ring of fultoportulae, but sometimes it is near the valve centre. The structure of the valve mantle is the same as that of the valve face. Numerous bands compose the very thin girdle. The valve is more silicified than the girdle (Fig. 9 B).

Skeletonema potamos has been recorded in the last 40 years from more and more localities in rivers and reservoirs in Europe (BELCHER and Swale 1978, StEINBERG et al. 1987, Chang and Steinberg 1988, Kiss and NAusch 1988) and South America (Torgan et al. 2009), both from freshwater to slightly brackish habitats, such as river estuaries. In many cases, it is one of the most abundant species of river phytoplankton in summer; it is a warm stenothermic species with high light demand (KISs et al. 1994). It is scarce in Hungarian running waters with a $9 \%$ occurrence rate (Fig. 9. C).

\section{Skeletonema subsalsum (Cleve-Euler) Bethge 1928 (Figs. 9 D-F)}

The species was described by CleVE-Euler (1912) as Melosira subsalsa and BeTHGE (1928) transferred it later to Skeletonema. HASLE and EVENSEN (1975), KLEE and STEINBERG (1987) and AKÉ CASTILLO et al. (1995) characterised its LM and EM morphology.

Skeletonema subsalsum is a typical chain-forming planktonic diatom. Adjacent cells are usually very close. Cells occurring tightly together have flattened valve faces. Valve is 

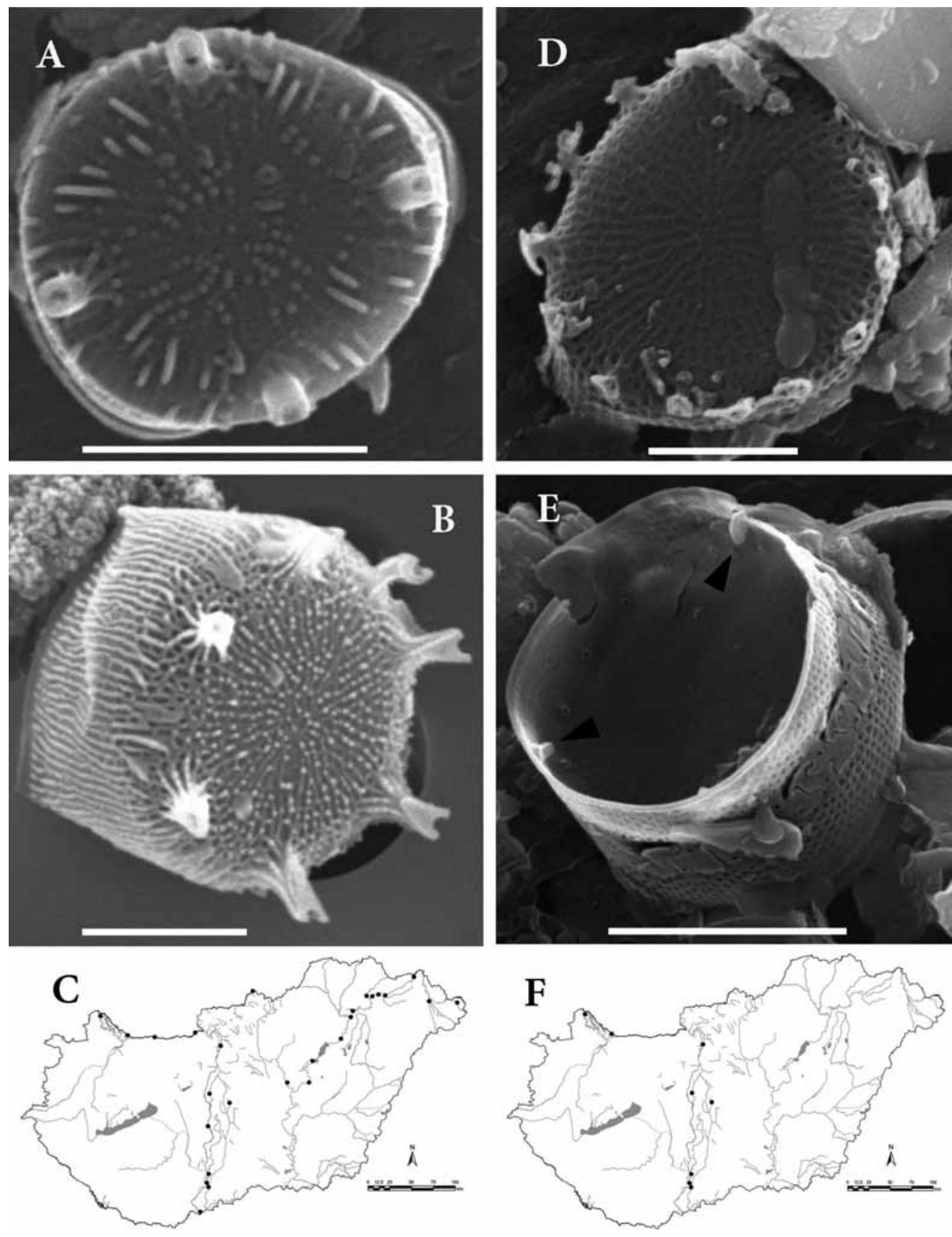

Fig. 9. A-B - Skeletonema potamos outside and semi-girdle view. D-E - S. subsalsum outside and inside view. C - distribution of S. potamos; F - S. subsalsum. Scale bar $5 \mu \mathrm{m}$ (E), $2.5 \mu \mathrm{m}$ (D) and $2 \mu \mathrm{m}(\mathrm{A}, \mathrm{B})$.

circular, diameter 3-6 $\mu \mathrm{m}$. The valve face is flat with typical Skeletonema structure with radially arranged striae of polygonal »areolae « and sometimes branched interfascicles (fine costa-like structure; Fig. 9 D). Valve mantle is different in length with parallel rows of rectangular areolae and interfascicles (Fig. 9 E). Frustules are connected with 7-14 marginal fultoportulae, which are flat (squeezed), flat-bifurcated or flat-spoon like, and provide a very close connection between valve mantles. Even when the fultoportulae are not really distinct from the mantle in their distal parts, the circular holes and the undulated distal outline of the fultoportulae are distinct (Fig. 9 E). The fultoportulae have short perpendi- 
cular, tubular parts internally with no longitudinal slits. The girdle consists of many narrow, weakly silicified bands. Among the fultoportulae a single rimoportula is situated.

Skeletonema subsalsum has been mostly recorded from saline and brackish water environments and is occasionally reported from freshwater localities (GIBSON et al. 1993). KRAMMER and LANGE-BERTALOT (1991) think its distribution is cosmopolitan. It is a rare species in Hungarian running waters with a $4 \%$ occurrence rate (Fig. $9 \mathrm{~F}$ ).

\section{$\underline{\text { Stephanodiscaceae }}$}

Cyclostephanos Round in Theriot et al. 1987

Cyclostephanos delicatus (Genkal) Casper et Scheffler 1990 (Figs. 8 D-F)

This species was described as Stephanodiscus delicatus by GenKaL (1985) from the River Volga in the Rybinsk Reservoir, Russia. KoBAYASI and KOBAYASHI (1987) and CASPER et al. (1988) published interesting complementary data about its LM and EM characteristics. Stephanodiscus delicatus was transferred to the genus Cyclostephanos by CASPER and SCHEFFLER (1990).

Valves circular; diameter 5-14 $\mu \mathrm{m}$, number of striae is $14-25 / 10 \mu \mathrm{m}$ (Fig. $8 \mathrm{D})$. The valve face has a clearly visible small central elevation or depression (frequently with a small annulus). The interfascicles can be branched (Fig. 8 E) and are generally slightly elevated on the external part of the valve face. On the internal valve face, interstriae are slightly elevated near the margin. They do not have a structure resembling real costae or alveolar chamber-like structure. Interstriae usually end in spines. This feature is less conspicuous on more heavily silicified valves. In this case the external valve face is almost smooth and the external openings of the areolae are smaller than on weakly silicified valves. A single valve face fultoportula can be seen in slightly eccentric position, internally with two satellite pores. Its round external opening is slightly elevated like a tiny volcano. Opposite to this elevated opening a small depression can be seen (the space of connecting valve face fultoportula). There are marginal fultoportulae on each interstria from $4^{\text {th }}$ to $7^{\text {th }}$ with a short tube externally and with two satellite pores internally. Among the marginal fultoportulae, a single rimoportula with small sessile labium can be found; its external opening is slightly elevated from the ring of marginal fultoportulae.

Cyclostephanos delicatus has been recorded from several eutrophic rivers and lakes; it has a medium frequency in Hungarian running waters with an $11 \%$ occurrence rate (Fig. 8 F).

\section{Cyclostephanos dubius (Fricke) Round in Theriot et al. 1987 (Figs. 10 A-C)}

This species was shown by FRICKE in SCHMIDT et al. (1874-1956) as Cyclotella dubia, and then was transferred by Hustedt (1928) to Stephanodiscus dubius. Round (1982) established the new genus Cyclostephanos and transferred S. dubius (Fricke) Hustedt to this genus. THERIOT et al. (1987) made a final validation of the genus name Cyclostephanos.

Frustule is short, cylindrical, $4.5-35 \mu \mathrm{m}$ in diameter. The valve face is concentrically undulate. There are radial rows of areolae (striae), which are multiseriate (2-4) near the margin and uniseriate in the centre (Fig. $10 \mathrm{~A}$ ). Interfascicles can be relatively fine, as in Stephanodiscus or strong costa-like as in Cyclotella, 12-18 in $10 \mu \mathrm{m}$. Internally, they form alveolar chambers (this is the most important characteristic of the genus). Areolae on valve mantle in groups, separated by thin end of interstriae or not separated. There are solid spines on the interfascicles near the margin, on some specimens on each interfascicle, on others only on a 

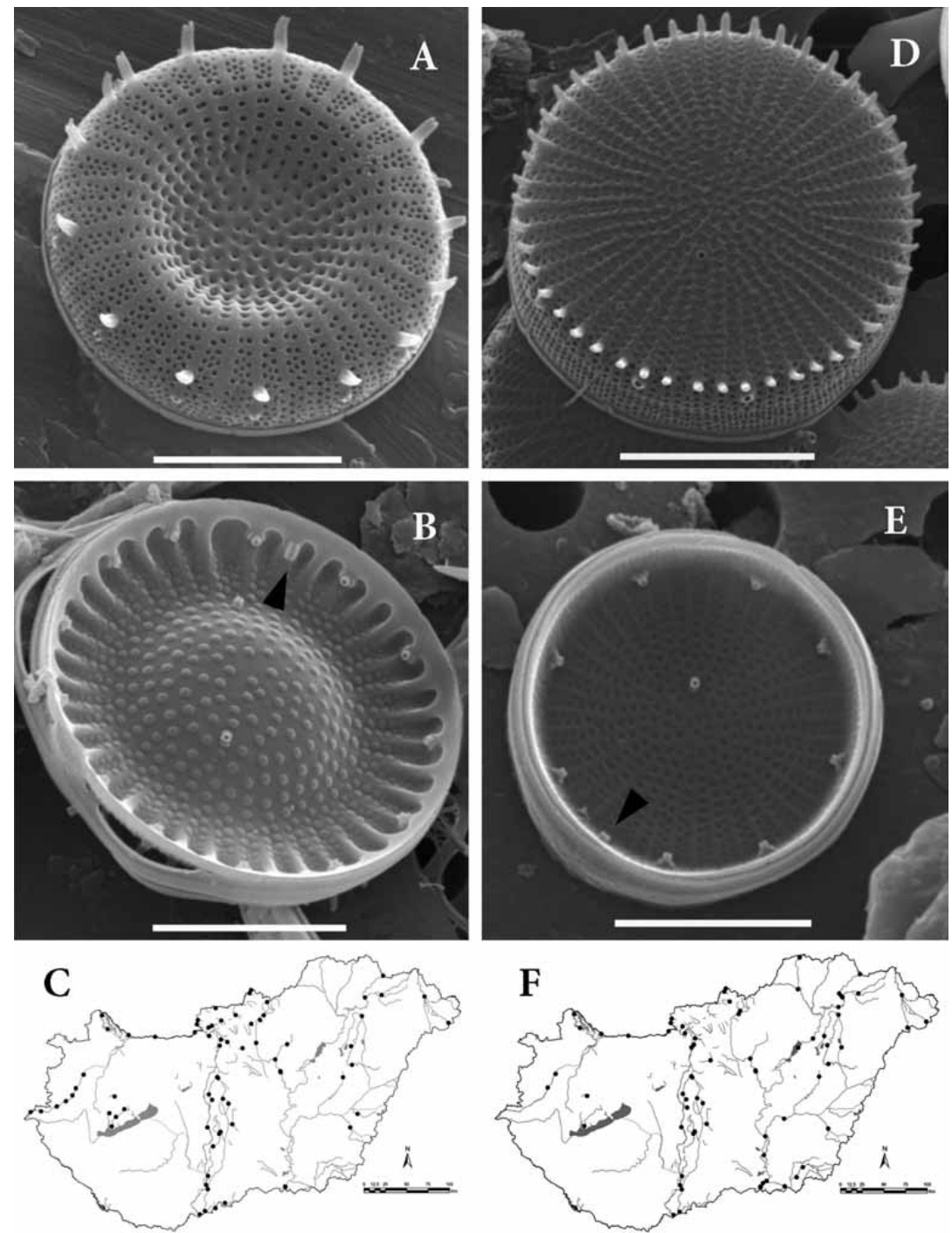

Fig. 10. A-B - Cyclostephanos dubius outside and inside view. D-E - C. invisitatus outside and inside view; $\mathrm{C}$ - distribution of $C$. dubius; F - C. invisitatus. Scale bar $5 \mu \mathrm{m}(\mathrm{A}, \mathrm{B}, \mathrm{D}, \mathrm{E})$.

few. Marginal fultoportulae are seen on every second to fifth costa with external openings below spines (Fig. $10 \mathrm{~B}$ ), the short internal tube with two satellite pores is on the costae. A few valve face fultoportulae with two satellite pores are situated close to the central or marginal area of the valve face (Fig. $10 \mathrm{~B}$ ). Their external openings are smaller than areolae. A single rimoportula can be seen between the marginal fultoportulae with a small labium on a costa.

Cyclostephanos dubius is cosmopolitan; it has been recorded frequently as an abundant species of river and shallow lake phytoplankton. It is frequent in Hungarian running waters with a $44 \%$ occurrence rate (Fig. $10 \mathrm{C}$ ). 
Cyclostephanos invisitatus (M. H. Hohn et Hellerman) Stoermer, Theriot et Håkansson in Theriot, Stoermer and Håkansson 1987 (Figs. 10 D-F)

This species was described by HoHn and Hellerman (1963) from the River Auglaize (Putman Co., Ohio) and also found in River Potomac (Maryland) and Ridley Creek (Pennsylvania). LowE and CRANG (1972) published important data about the ultrastructure of this species with TEM and SEM, investigating material from Susquehanna River near Berwick, Pennsylvania, USA. THERIOT et al. (1987) transferred this species to the genus Cyclostephanos.

The frustule is cylindrical, diameter $5-14 \mu \mathrm{m}$, the length of the pervalvar axis is half-three quarters of the diameter (Fig. $10 \mathrm{D}$ ). The valve face is flat; it consists of radial rows (striae) of poroid areolae (one areola in the centre and 2-3 near the margin). Number of striae is $14-22 / 10 \mu \mathrm{m}$, that of areolae is $20-40 / 10 \mu \mathrm{m}$. In the centre a small, more or less regular rosette is situated, formed by an annulus around some areolae. Near this annulus one, rarely two, valve face fultoportula(e) internally with two satellite pores. Interstriae are more or less straight, some of them with bifurcation on the valve face. They are bifurcated or straight under spines on the valve mantle. There are small spines at valve mantle, valve face junction on each interstria; marginal fultoportulae with two satellite pores are situated on each stria from 3 to 6 and a rimoportula among them with a small sessile labium. The external opening of the rimoportula is a slightly elevated pore in the ring of marginal fultoportulae. On the internal valve face, interstriae are slightly elevated near the margin (Fig. 10 E). They do not have a structure resembling real costae or an alveolar chamber-like structure.

Cyclostephanos invisitatus was described as a unicellular form. In the River Danube, however, especially in summer, short chains of a few cells are frequently recorded, even up to 10-15 cells. Chains are formed by connection of spines. Frustules of the chains have normal or flat spines, sometimes with spoon-like broadenings or bifurcations resembling $S$. binderanus (KIss 1988).

Cyclostephanos invisitatus is a cosmopolitan species and has been recorded from many eutrophic rivers and lakes. It is the third most frequent species in Hungarian running waters with a $45 \%$ occurrence rate (Fig. $10 \mathrm{~F}$ ).

Cyclotella (Kützing) Brébisson 1838 nom. cons. Cyclotella atomus Hustedt 1937 var. atomus (Figs. 11 A-C)

The species was described by HustedT (1937) from the plankton of the Sindanglaja Reservoir situated in West Java, Indonesia. Detailed data were published on the EM structure of species, description of a new variety by GENKAL and KISS (1993).

Frustule cylindrical, the valve face is flat (smooth) or slightly undulated (Fig. $11 \mathrm{~A})$. The diameter is $3.5-8.0 \mu \mathrm{m}$. Length of pervalvar axis is similar to or smaller, and occasionally bigger, than the diameter.

Striated marginal part of the valve face is larger than the half radius. The central hyaline area is small. Striae have 1-3 areolae close to the centre and 5-7 close to the margin (Fig. 11 A). Number of striae is $15-20 / 10 \mu \mathrm{m}$. There is no »real « alveolar structure (alveoli on the marginal part of the valve face are not clearly distinguished from the central hyaline area), on the internal valve face, only »open « alveoli (the alveolar chamber is not closed in direction of centre (Fig. $11 \mathrm{~B}$ ). On the valve margin, there is a ring of 5-9 fultoportulae, which have small pores externally near the valve face and valve mantle junction and they 
Kiss K. T., KLEE R., Ector L., Ács É.
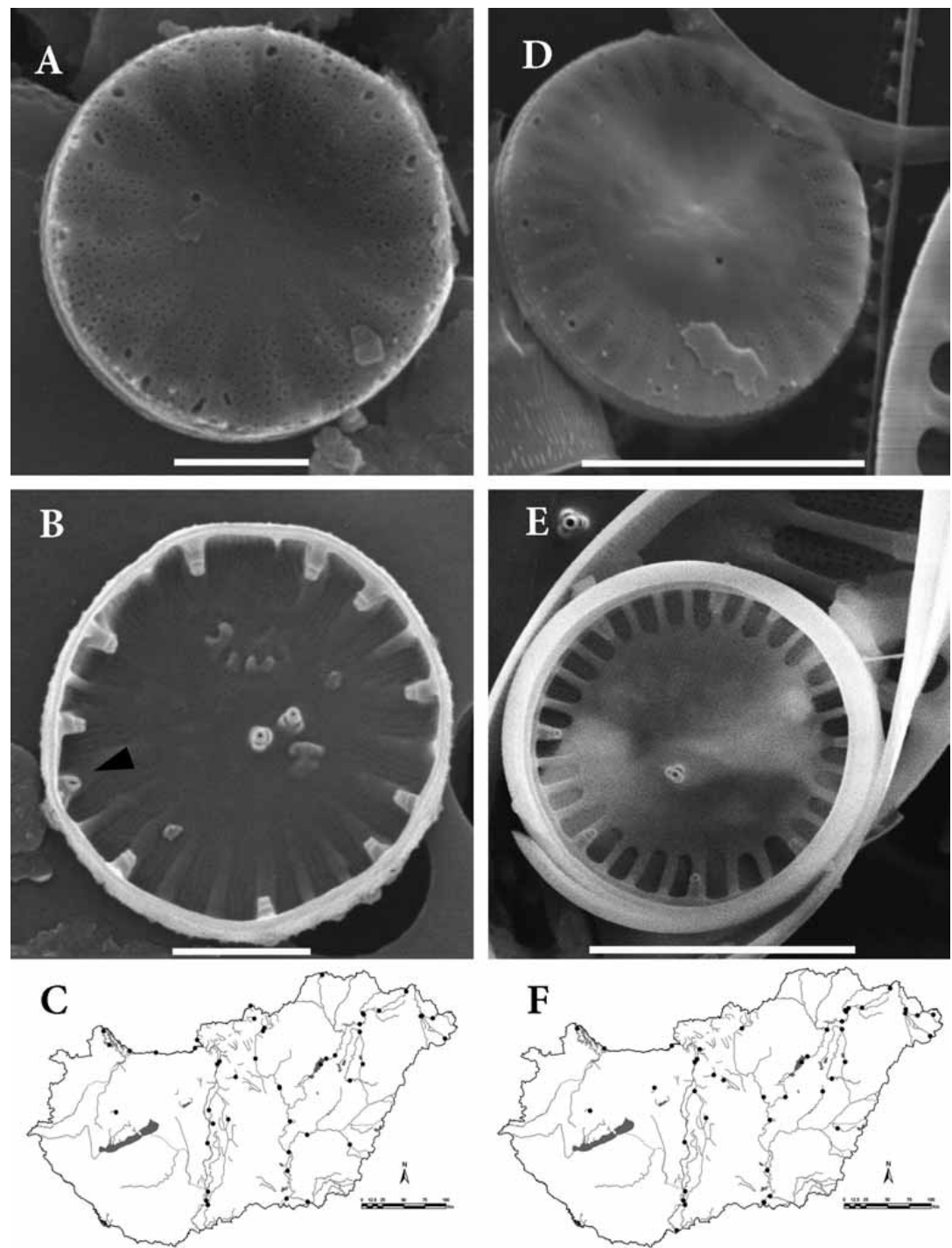

Fig. 11. A-B - Cyclotella atomus var. atomus outside and inside view. D-E - C. atomus var. gracilis outside and inside view. $\mathrm{C}$ : - distribution of $C$. atomus var. atomus; $\mathrm{F}-C$. atomus var. gracilis. Scale bar $5 \mu \mathrm{m}(\mathrm{D}, \mathrm{E})$ and $2 \mu \mathrm{m}(\mathrm{A}, \mathrm{B})$.

are situated on each costa from $2^{\text {nd }}$ to $4^{\text {th }}$ and have two satellite pores. On the valve margin, a single rimoportula is visible internally and on the central hyaline area one (rarely two) valve face fultoportula with three satellite pores in eccentric position.

Cyclotella atomus var. gracilis Genkal et K. T. Kiss 1993 (Figs. 11 D-F)

The striated marginal part of the valve face is about half the length of the radius. The central hyaline area is relatively large. Striae have 2-3 areolae close to the centre and 5-6 close to the margin (Fig. 11 D). Number of striae is $15-20 / 10 \mu \mathrm{m}$. This variety has a »real« 
alveolar structure (alveoli on the marginal part of the valve face are clearly distinguished from the central hyaline area). Internally alveolar chambers are circularly closed in direction of centre (Fig. 11 E). There is a ring of 5-9 fultoportulae on the valve margin, which have small pores externally near the valve face and valve mantle junction and they are situated on each costa from $2^{\text {nd }}$ to $4^{\text {th }}$ and have two satellite pores. A single rimoportula can be seen internally positioned on the valve margin and on the central hyaline area one valve face fultoportula with three satellite pores in an eccentric position.

Both varieties of $C$. atomus were recorded from different eutrophic rivers and lakes in Europe. It is a euryhaline, cosmopolitan species. It has a medium frequency in Hungarian running waters, C. atomus var. atomus with a $24 \%$, C. atomus var. gracilis with a $20 \%$ occurrence rate (Figs. $11 \mathrm{C}, \mathrm{F}$ ).

Cyclotella choctawhatcheeana A. K. S. Prasad in Prasad, Nienow and Livingston 1990 (Figs. 12 A-C)

The species was described by PRASAD et al. (1990) from the Choctawhatchee Estuary from the Gulf of Mexico. Later it was newly described as C. hakanssoniae Wendker (WENDKER 1991) from the Schlei Estuary (Germany); this taxon is a synonym of $C$. choctawhatcheeana. A recent paper presents many details about the valve morphology (BuRIĆ et al. 2007).

Unicellular, but can form short chains occasionally. The diameter of the cells varies between 6-15 $\mu \mathrm{m}$ with $20-27$ striae in $10 \mu \mathrm{m}$. The valve face has a tangential undulation of the central area with a colliculate structure (Fig. 12 A). These features are lightly marked on small valves and pronounced on large ones. The striated marginal area consists of striae and interstriae continuing into the mantle. The striae have 1-3 very small areolae (pores) near the undulated central area and 2-5 close to the margin. The interstriae are thin and terminate close to the edge of the valve face. The openings of the alveolar chambers are slightly elongated. There are 1-8 valve face fultoportulae, arranged in a semicircle, internally with three satellite pores (Fig. 12 B). The external pores of valve face fultoportulae are situated on the elevated part of the tangential undulation. There are openings of the mantle fultoportulae on every second to fourth interstria near the edge of the valve with a small round pore externally and two satellite pores internally. The rimoportula has an elongated external hole and an elongated slit internally. The lip of the rimoportula is in radial position or at different angles to the costae.

Cyclotella choctawhatcheeana has been found in different localities around the world in brackish waters and rivers connected with saline lakes. It seems an invasive species in eutrophic brackish waters. It is a rare species in Hungarian running waters with a $2 \%$ occurrence rate (Fig. 12 C).

\section{Cyclotella delicatula Hustedt 1952 (Figs. 12 D-F)}

The species was described by HUSTEDT (1952) from the plankton of a small groundwater lake (Seebachlacke, Lower Austria). Detailed morphology based on LM and SEM studies from the Austrian type material was published by SCHEFFLER et al. (2003) and Houk et al. (2010). It was also found in a Spanish karstic lake and illustrated by KISS et al. (2007).

Frustules are cylindrical, diameter 3.2-11.0 $\mu \mathrm{m}$, length of the pervalvar axis is $1.5-3.0 \mu \mathrm{m}$. The central part of the valve face is flat and slightly domed towards the mantle. The central area is smooth, round or polygonal (Fig. 12 D) decorated with only the opening of the valve face fultoportula or with round to irregular small hollows, which never penetrate the silica 

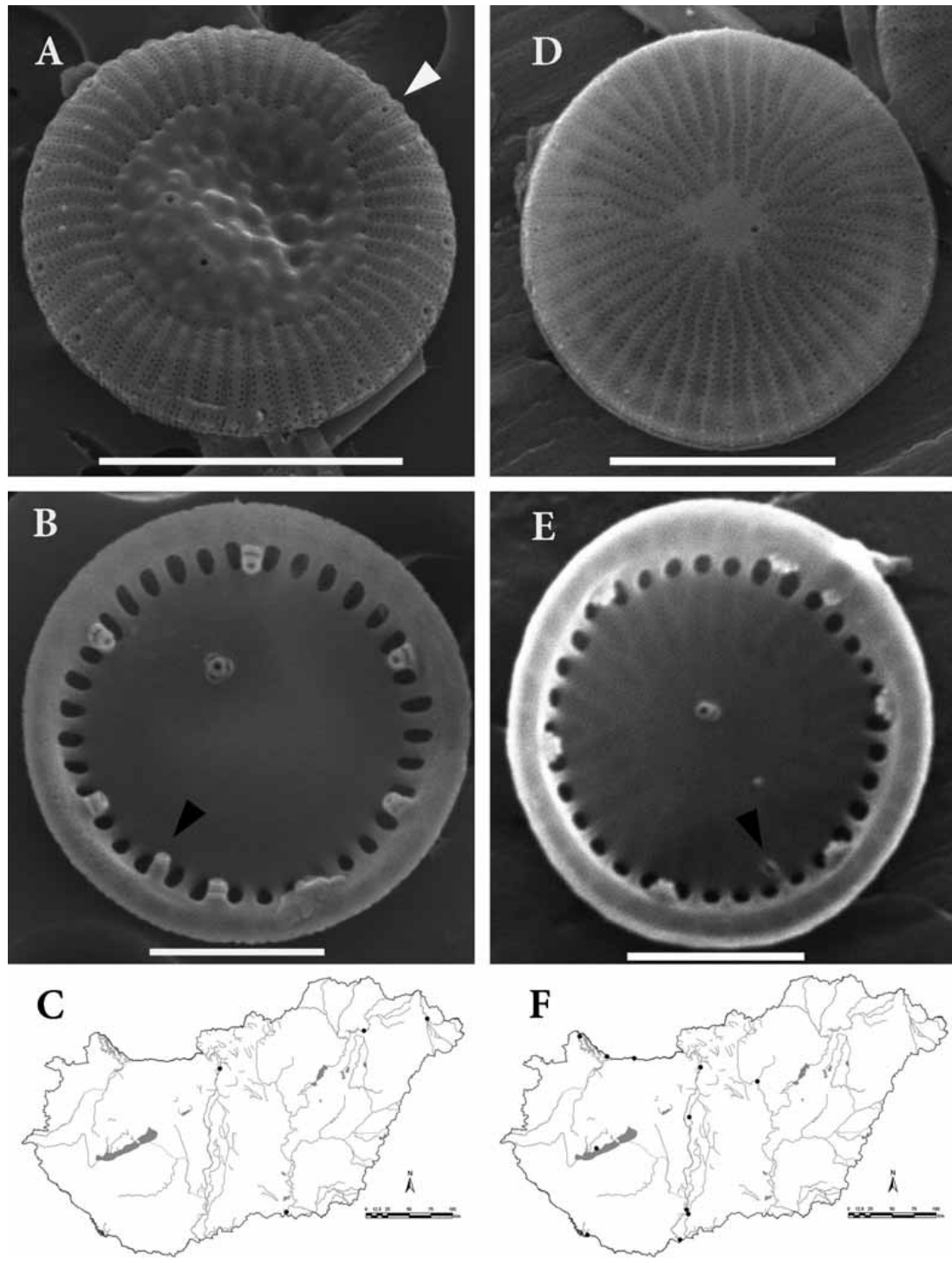

Fig. 12. A-B - Cyclotella choctawhatcheeana outside and inside view. D-E - C. delicatula outside and inside view; $\mathrm{C}$ - distribution of $C$. choctawhatcheeana; F - C. delicatula. Scale bar $5 \mu \mathrm{m}$ (A, D) and $2 \mu \mathrm{m}(\mathrm{B}, \mathrm{E})$.

layer of the valve face. Outside of central hyaline area the valve face is structured by striae formed by areolae and interstriae $15-26 / 10 \mu \mathrm{m}$. At the edge of the interstriae two or three small areolae are normally situated between two large areolae but striae with three or six to seven areolae have also been found. The striae are usually unequal in length; therefore the central area is frequently polygonal (Fig. 12 D). Interstriae are relatively narrow and never straight, sometimes decorated with one or two rings of small granules near the periphery of the valve. Several stria and interstria are branched. The valve has one valve face fultoportula 
close to the centre, its external opening is relatively large and sometimes difficult to distinguish from small hollows by SEM. Internally it has a short tube and usually two satellite pores (Fig. $12 \mathrm{E}$ ). A ring of fultoportulae is situated on the valve margin with two satellite pores. The external opening of the marginal fultoportulae is a relatively large pore on four to six costae. The inner aperture of the alveolar chamber is round to elongate. The costae bearing fultoportulae can be slightly depressed. The single rimoportula is situated on the valve face. Its external opening is a relatively large pore at about one third of the radius, usually on a branched interstria. The position of the labium varies.

Cyclotella delicatula has been recorded first of all from mesotrophic lakes and from rivers with connection to lakes. It is a scarce species in Hungarian running waters with a $6 \%$ occurrence rate (Fig. 12 F).

\section{Cyclotella distinguenda Hustedt 1927 (Figs. 13 A-C)}

The species was described by HUSTEDT (1927) from the Lower Lunz Lake (Lunzer Untersee) in Austria. HÅKANSSON (1989) published high quality micrographs from the original Hustedt material and she compared Cyclotella distiguenda with C. operculata (C. Agardh) Kützing and C. plitvicensis Hustedt. New illustrations were published on Hustedt's original type material and Kützing's material from Tennstädt in Germany by HÅKANSSON (2002) and Houk et al. (2010), and from Lake La Cruz in Spain by KIss et al. (2007).

Valve is circular, diameter 9-24 $\mu \mathrm{m}$, length of pervalvar axis 4-6 $\mu \mathrm{m}$. The central part of the valve face has a tangential undulation (Fig. $13 \mathrm{~A}$ ), which can be pronounced or slight. It is smooth or decorated with verrucae, with smaller or larger pores and frequently with special shaped wavy lines at the base of the undulation. The marginal part of the valve is structured by striae and interstriae, $10-14 / 10 \mu \mathrm{m}$. Interstriae are relatively narrow and on a few valves they are quite inconspicuous. Striae are formed by areolae, usually two larger areolae are situated at both sides of the interstriae and one or two small ones are located between them. The number of areolae increases towards the margin and on the valve margin there are 4-5/striae. Striae are equal in length and never diverge on the flat part of the valve face, however they do diverge at the valve mantle border and on the mantle in $\sim 25 \%$ of the valves and lose their distinctness. There is no valve face fultoportula but valves display a ring of marginal fultoportulae situated near the junction between the valve face and the mantle, their external openings are round pores, larger than the areolae and are visible on interstriae. Internally fultoportulae have three satellite pores and a relatively long cowling (Fig. 13 B). The position of the marginal fultoportulae varies, usually on every second to fourth costa. Costae are more or less equal in length. The alveolar chambers are usually round on small valves or elongated on large ones. The single rimoportula is situated on the same level as the fultoportulae. It has a short tube with a large labium, usually parallel, but can be at a slight oblique to the valve face (Fig. 13 B). The external opening of the rimoportula varies from round to elongate.

Cyclotella distinguenda has been recorded from mesotrophic lakes and from rivers with connection to lakes. It is rare in Hungarian running waters with a $1 \%$ occurrence rate (Fig. $13 \mathrm{C})$.

\section{Cyclotella meduanae H. Germain 1981 (Figs. 13 D-F)}

The species was described and illustrated in LM and TEM by GERMAIN (1981) from the lower part of the River Mayenne at Angers (France); GERMAIN also found this Cyclotella in 
Kiss K. T., KLEE R., Ector L., Ács É.
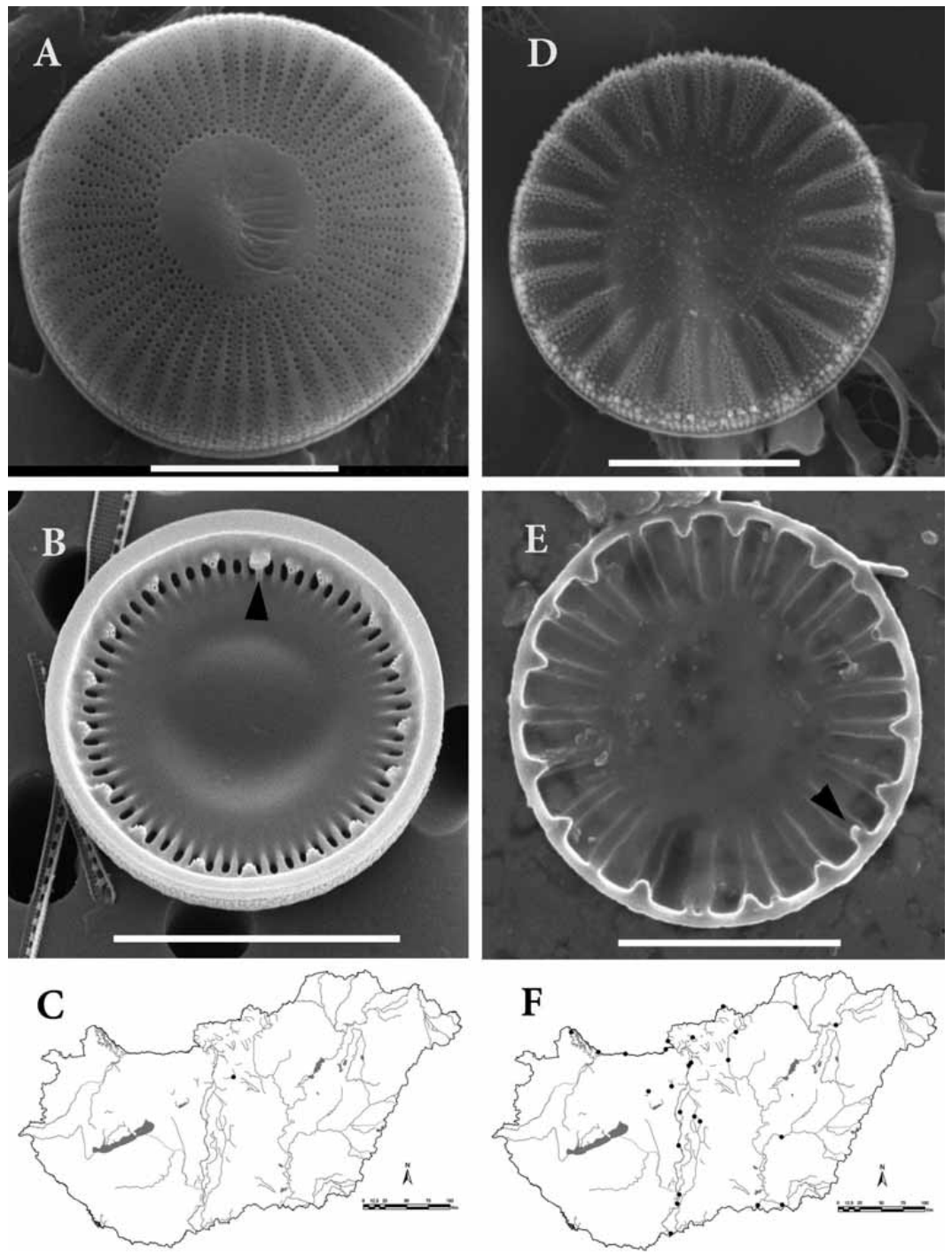

Fig. 13. A-B - Cyclotella distinguenda outside and inside view. D-E - C. meduanae outside and inside view; $\mathrm{C}$ - distribution of $C$. distinguenda; F - C. meduanae. Scale bar $10 \mu \mathrm{m}$ (B) and 5 $\mu \mathrm{m}(\mathrm{A}, \mathrm{D}, \mathrm{E})$.

the River Maine, another tributary of the River Loire. No SEM pictures from the type material have ever been published (Houk et al. 2010).

Unicellular but can form short chains occasionally. Frustule cylindrical, valve face flat (smooth), diameter 5-8 $\mu \mathrm{m}$. The length of the pervalvar axis is about half the length of the diameter. The striated part of the valve face is clearly divided from the central hyaline area (Fig. 13 D). Diameter of central hyaline area is less than half the length of the diameter. Number of striae is $13-16$ in $10 \mu \mathrm{m}$. Alveoli consist of 7-10 radial rows of fine laminate areolae. Interfascicles form costae or costae-like structures on the internal valve face and 
smooth alveolar chambers. Marginal fultoportulae with three satellite pores are situated on every second-third interstria (costa). External openings of marginal fultoportulae and rimoportula are well-developed pores. Rimoportula is situated between marginal fultoportulae; it has a small labium (Fig. 13 E). Many granules and spinules can be seen on the valve margin. Central area is without fultoportula.

This species resembles a small $C$. meneghiniana concerning the structure of the valve face but it has no central fultoportula and there are no marginal fultoportulae in each interstria. It can be distinguished from $C$. atomus by the distinct central and marginal area and by the lack of a central fultoportula.

Cyclotella meduanae has been recorded from different rivers and lakes with different halobity and trophic status. It has a medium frequency in Hungarian running waters with a $14 \%$ occurrence rate (Fig. 13 F).

\section{Cyclotella meneghiniana Kützing 1844 (Figs. 14 A-C)}

The species was described and illustrated by KüTZING (1844) in material from Ferrara (Emilia-Romagna region, northern Italy) and the illustrations were made after Meneghini's specimens. HÅKANSSON (1990) presented detailed morphological criteria reinvestigating the Italian type material of Cyclotella meneghiniana (Figs. 1-3, 5-17) and also the type material of the synonym Cyclotella kuetzingiana (Figs. 19-30), collected in Shirehampton near Bristol.

Frustules drum-shaped, the valve face in girdle view more or less tangentially undulate. Valve face is circular, 5-43 $\mu \mathrm{m}$ in diameter, with well-defined marginal, striate zone and structureless or more or less radially streaked central hyaline area (Fig. 14 A). Marginal zone is about one half of the length of the radius with prominent radial striae 6-10 in $10 \mu \mathrm{m}$. Striae consist of an alveolus, closed externally by an arched areolate layer forming the external ridges of the marginal zone. Alveoli are distinctly separated by solid costae (Fig. 14 B), corresponding externally to the furrows between the arched outer layer of striae. There are 1-7 valve face fultoportulae on one side of the slight tangential fold, internally surrounded by three satellite pores. Marginal fultoportulae with three satellite pores project slightly onto the inner side of the valve, while the external opening is more or less flush with the valve mantle. Interfascicles distinct with well-developed spines near the margin (in some cases there are spinules and/or small granules near the spines). Below the spines marginal fultoportulae penetrate each interstria. A single rimoportula with a well-developed labium is present on one of the costae at the same level as marginal fultoportulae.

Cyclotella meneghiniana is cosmopolitan, frequent and abundant in rivers and lakes, under different trophic conditions. Houk et al. (2010) defined it as a common species in the littoral and pelagic zone of eutrophic stagnant waters or slowly running rivers. It is the most frequently encountered species in Hungarian running waters with a $61 \%$ occurrence rate (Fig. 14 C).

\section{Cyclotella scaldensis Muylaert et Sabbe 1996 (Figs. 14 D-F)}

The species was described by MUYLAERT and SABBE (1996) from plankton of the estuary of the River Schelde in Belgium. GENKAL et al. (2008) described and illustrated with SEM the species Cyclotella ambigua Grunow from the phytoplankton of the Kuibyshev Reservoir (River Volga) and considered this taxon conspecific with Cyclotella scaldensis, but they never investigated material from the type locality (River Yenisei, Siberia, Russia). The 

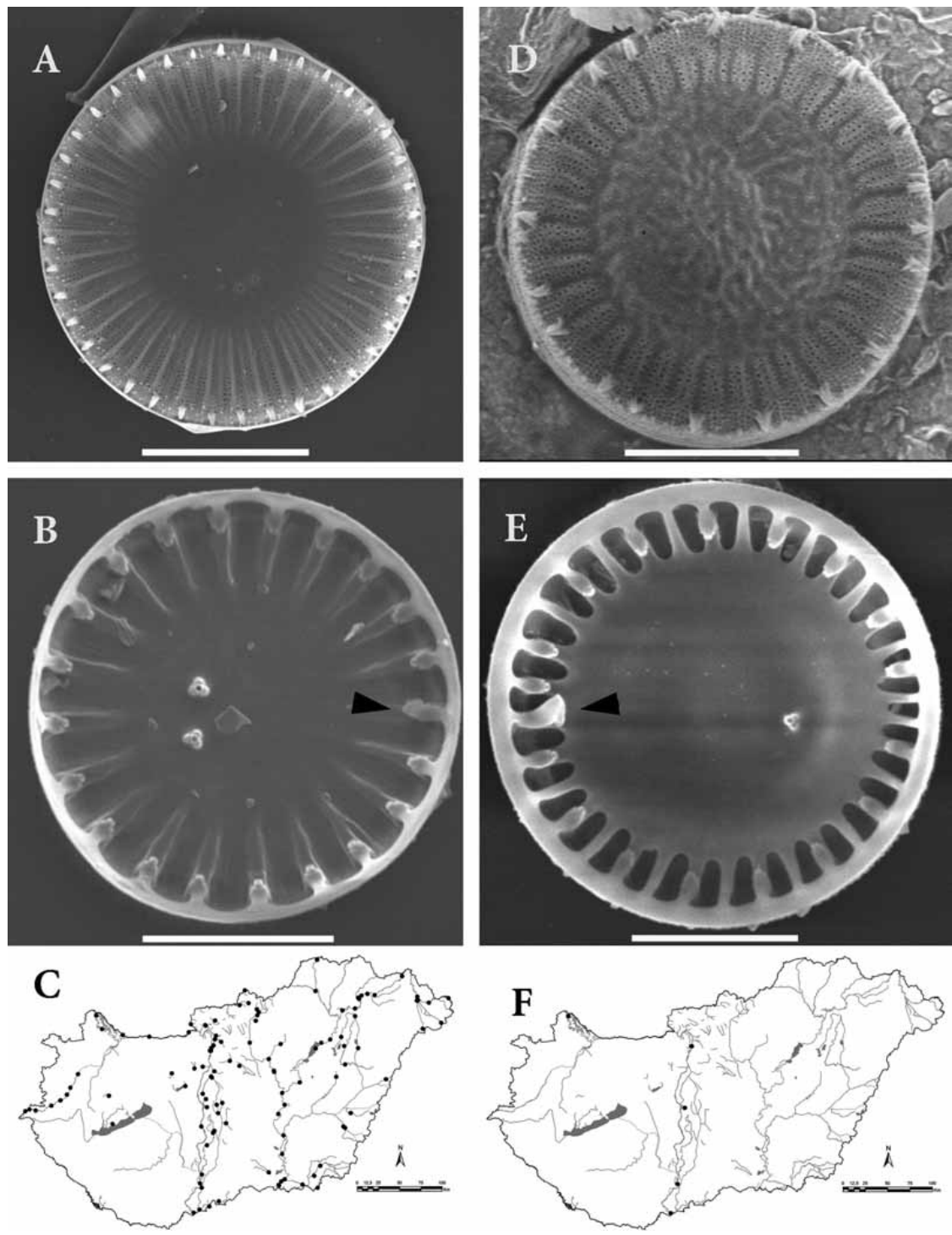

Fig. 14. A-B - Cyclotella meneghiniana outside and inside view. D-E - C. scaldensis outside and inside view; $\mathrm{C}$ - distribution of C. meneghiniana; F-C. scaldensis. Scale bar $10 \mu \mathrm{m}$ (A) and $5 \mu \mathrm{m}(\mathrm{B}, \mathrm{D}, \mathrm{E})$.

type population of Cyclotella ambigua has been illustrated only with LM by Houk et al. (2010), but there is no type material for SEM investigation in the Grunow Collection in Vienna. For these reasons we prefer to keep the denomination of Cyclotella scaldensis for the specimens found in Hungarian watercourses.

Frustules are cylindrical with a diameter of 7-34 $\mu \mathrm{m}$. Valve face in girdle view with a strong tangentially undulate central part which is colliculate, with more or less radially arranged colliculae (Fig. 14 D). The marginal striated zone comprises less than $1 / 2$ of the 
valve radius. Marginal zone with prominent radial striae, 7-13 in $10 \mu \mathrm{m}$. Striae have 3-7 radial rows of pores; external are larger than internal pores. Each stria consists of a single alveolus closed externally by an arched areolate layer forming the external ridges of the marginal zone. Internally, the alveoli are distinctly separated by solid costae (Fig. 14 E), corresponding externally to the furrows between the arched outer layer of the alveoli (striae). Interstriae terminate with spines. Not every interstria has spines. Below the spines, marginal fultoportulae are situated on every second to fourth interstria. The marginal fultoportulae with three satellite pores project slightly onto the inner side of the valve. The external opening of marginal fultoportulae are more or less flush with the valve mantle. The single rimoportula is located at the same level as, or slightly lower than the marginal fultoportulae. The rimoportula is elongated and flattened, appears bell-like from the edge of the valve and varies from a simple to spirally flattened tube with its aperture positioned parallel with, or twisted to the edge of the valve. Externally the rimoportula has a thickened round aperture. The valve face fultoportulae (1-9) with three satellite pores are located on the convex part of the central area and externally look like round pores.

Cyclotella scaldensis is a planktonic species, found in brackish to freshwaters, rather eutrophic and slowly running rivers and estuaries (Houk et al. 2010). It is a rare species in Hungarian running waters with a $2 \%$ occurrence rate (Fig. 14 F).

\section{Cyclotella ocellata Pantocsek 1901 (Figs. 15 A-C)}

PANTOCSEK (1901) described Cyclotella ocellata (and his synonym C. crucigera) from sediment of Lake Balaton collected in Siófok. Investigations of type slides and type material by HÅKANSSON (1993), KISS et al. (1999) and HouK et al. (2010), and of populations of the Gallbergweiher, Germany (HEGEWALD and HindÁKOVA 1997) and Lake Khubsugul, Mongolia (GENKAL and POPOVSKAYA 2008) helped us to understand better the large morphological variability of this species.

Frustules are disc-shaped, solitary or rarely in short chains, $4-44 \mu \mathrm{m}$ in diameter, length of pervalvar axis $2-6 \mu \mathrm{m}$. The valve face has orbiculi depressi zero to seven; their numbers can vary on the epi- and hypovalve. Their inverse place is the papilla postament (the round spot on the place where the papilla was fixed; Fig. 15 A). Besides orbiculi depressi, there are a few relatively small punctae. The central part of the valve is more or less flat, it can be relatively small or large, not depending on the diameter, and contains different-sized and spaced colliculate protuberances. The marginal part of the valve is structured by 14 to 20 striae and interstriae in $10 \mu \mathrm{m}$. Usually a row of small areolae is situated between two rows of large areolae on the valve face. Interstriae different in length, a few of them forked. Small granules are observed on the interstriae near the margin on most valves and found sporadically on the striae. Valve face fultoportulae (1-13, rarely any fultoportula) are usually surrounded by two satellite pores. In many cases, the external openings of these fultoportulae are very difficult to observe, because many valves have some small holes, which are arranged irregularly in the central part. Generally, every third to fifth interstria bears a marginal fultoportula but it may occur on each to every 6th interstria. The internal openings are surrounded by two satellite pores. One rimoportula is situated in the marginal area (Fig. 15 B). Costae are usually equal in length but those bearing a fultoportula are often shorter. The inner aperture of the alveoli can be round or elongated. The valve usually has a single rimoportula (sometimes two or more) and the orientation of the lip varies.

Houk et al. (2010) define this centric species as a littoral and pelagic species of mostly standing, oligo- to eutrophic waters, particularly with sandy or gravelly bottom, also found in 
Kiss K. T., KleE R., Ector L., Ács É.
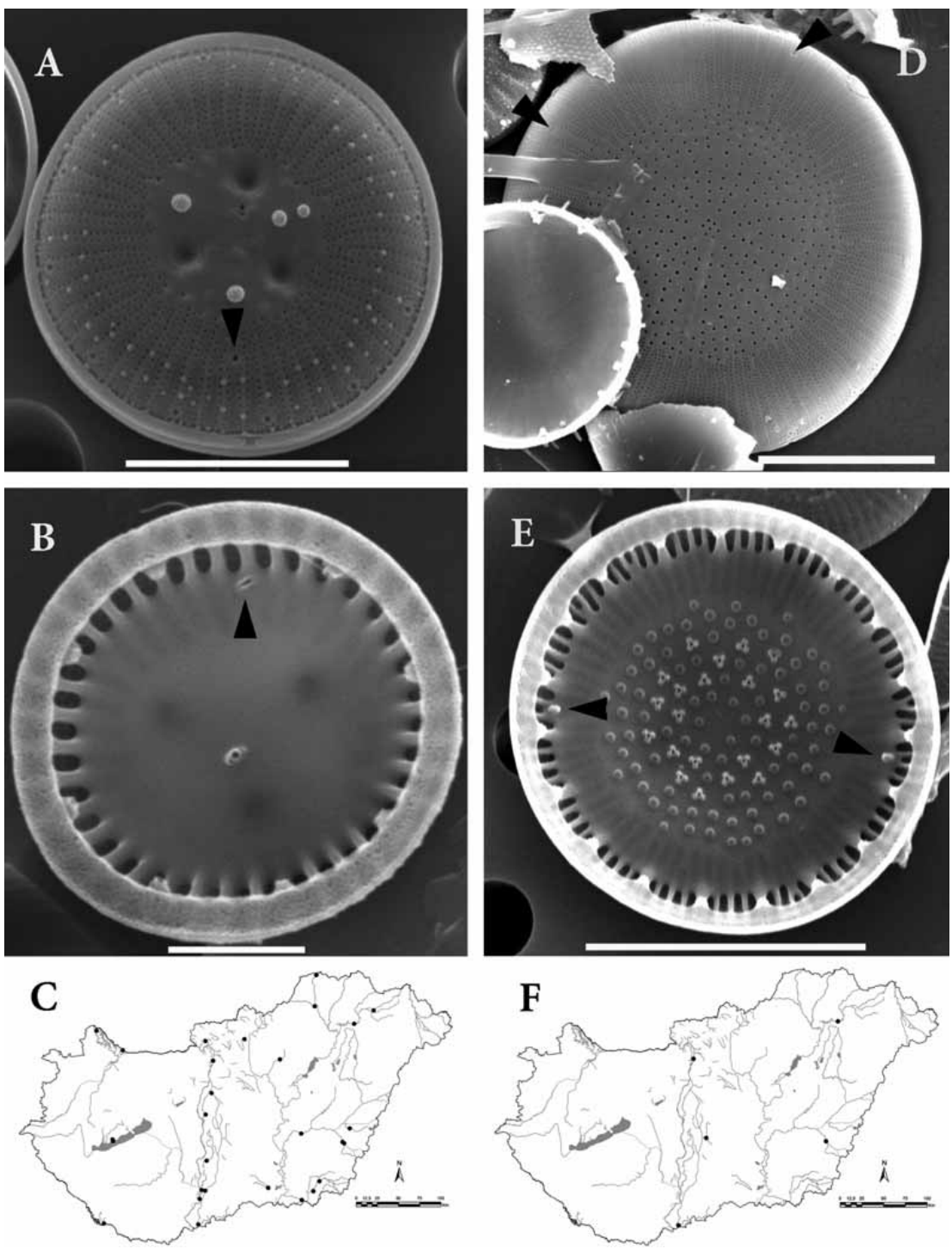

Fig. 15. A-B - Cyclotella ocellata outside and inside view. D-E - C. balatonis outside and inside view; $\mathrm{C}$-distribution of C. ocellata; F-C. balatonis. Scale bar $10 \mu \mathrm{m}$ (D, E), $5 \mu \mathrm{m}$ (A) and $2 \mu \mathrm{m}$ (B).

slowly flowing rivers. It seems to be in close correlation with relatively high $\mathrm{Ca}^{2+}$ ion concentration. It has a medium frequency in Hungarian running waters with a $23 \%$ occurrence rate (Fig. 15 C).

Cyclotella balatonis Pantocsek 1901 (Figs. 15 D-F)

Cyclotella balatonis was described by PANTOCSEK (1901) from Lake Balaton (Hungary). Houk et al. (2010) published a detailed morphological description of the species based on LM and SEM investigation of the type material; it has been found in Hungary 
(Lake Balaton), Germany (Lakes Abtsdorfer See, Grosser Uleisee, Tachinger See, Waginger See), and the Czech Republic (Želivka Reservoir, River Vltava). According to BuDZYÑSKA and Wojtal (2011), the limited number of citations of this centric diatom may be related to its misidentification or confusion with other Cyclotella species; they observed it in the plankton of the eutrophic-hypertrophic Rusałka Lake (Western Poland) and proposed the new combination Puncticulata balatonis (Pantocsek) Wojtal et Budzyñska.

Cells solitary or in short, loosely united chains of 2-8-cells. Valve face is flat or slightly concave or convex, diameter 16-22 $\mu \mathrm{m}$ (Fig. 15 D). Central area is frequently reticulate-verrucose with areolae (internally with domed cribra) and small openings of valve face fultoportulae with three satellite pores. Areolae are not strictly radially arranged. Marginal area with striae $14-17 / 10 \mu \mathrm{m}$ having two radial rows of areolae with tiny punctae between them and increase in number towards the valve margin. Striated part takes about half of the radius (or a little bit less). Interstriae slightly unequal in length, continue onto the mantle, become narrow below the marginal fultoportula opening. Several interstriae divide (this is not very visible with LM). Every third-fourth interstria is thicker (shadow-line) and bears externally the round opening of the marginal fultoportulae. The fultoportula' tubules have two satellite pores which are situated internally on the thickened ribs that are separated by 2-4 thinner costae (Fig. 15 E). Usually 2-5 (sometimes only one) round rimoportula opening is situated on the valve face at the end of a shortened stria close to the margin, internally with a sessile labium positioned radially or slightly diagonally.

Cyclotella balatonis can be characterized as a freshwater species of mesotrophic or slightly eutrophic lakes, reservoirs and slowly flowing rivers. It is rare in Hungarian running waters with a $5 \%$ occurrence rate (Fig. $15 \mathrm{~F}$ ).

\section{Cyclotella praetermissa J. W. G. Lund 1951 (Figs. 16 A-C)}

The species was described by Lund (1951) from the plankton of Blelham Tarn (Lake District, Cumbria, North West England). It was transferred to the new genus Puncticulata by HÅKANSSON (2002). HouK et al. (2010) proposed to retain the previous generic name Cyclotella for the Puncticulata taxa and we agree with their proposal.

Cells solitary or in short, loosely united chains of 2-7-cells. Valves concentrically undulate, diameter 8-25 $\mu \mathrm{m}$ (Fig. $16 \mathrm{~A}$ ). Central area is frequently reticulate-verrucose with areolae (internally with domed cribra) and small openings of valve face fultoportulae in circular pattern (internally with three satellite pores). The areolae are not strictly radially arranged. Marginal area with striae 11-19(22)/10 $\mu$ m having two radial rows of areolae with tiny punctae between them and increase in number towards the valve margin. Interstriae slightly unequal in length continue onto the mantle, become narrow below the marginal fultoportula opening. Every fourth (3-6) interstria is thicker (shadow-line) and bears externally the round opening of the marginal fultoportulae. The fultoportula tubules have two satellite pores internally on the thickened ribs, which are separated by 3-7 thinner costae (Fig. 16 B). Usually one (sometimes two) round rimoportula opening is situated on the valve face at the end of a shortened stria, internally with a sessile labium positioned radially or slightly diagonally.

Cyclotella praetermissa can be characterized as a freshwater, probably mesohalobous species and can be found in several eutrophic or polluted lakes and rivers. It is rare in Hungarian running waters with a $1 \%$ occurrence rate (Fig. $16 \mathrm{C}$ ). 

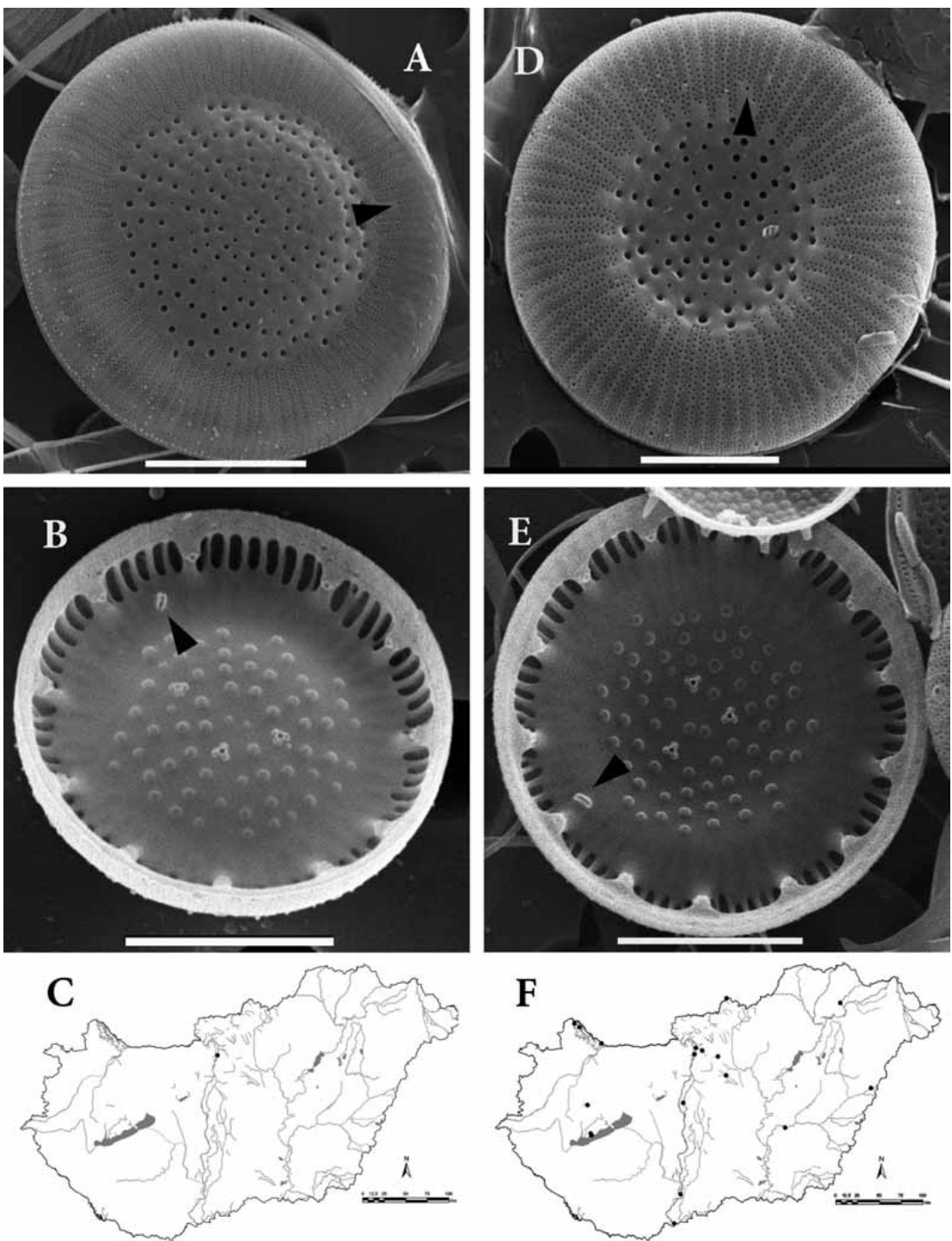

Fig. 16. A-B - Cyclotella praetermissa outside and inside view. D-E - C. radiosa outside and inside view; C-distribution of C. praetermissa; F-C. radiosa. Scale bar $10 \mu \mathrm{m}(\mathrm{A})$ and $5 \mu \mathrm{m}(\mathrm{B}, \mathrm{D}, \mathrm{E})$.

Cyclotella radiosa (Grunow) Lemmermann 1900 (Figs. 16 D-F)

The species was found in Lake Mondsee (Vöcklabruck district, Upper Austria) and illustrated as Cyclotella comta var. radiosa Grunow (VAN HEURCK 1882). LEMMERMANN (1900) proposed the specific name $C$. radiosa (Grunow) Lemmermann. HÅKANSSON (2002) transferred this taxon to the genus Puncticulata but Houk et al. (2010) preferred to retain the previous generic name Cyclotella.

Central area of valves slightly concave or convex, characterised by radial rows of punctae (loculate areolae, Fig. 16 D) internally with domed cribra and irregularly arranged external 
openings of valve face fultoportulae (internally surrounded by 3 satellite pores, Fig. $16 \mathrm{E}$ ). Diameter is $7-35 \mu \mathrm{m}$; marginal area with striae with three (four) punctate rows of areolae (13-16 striae/10 $\mu \mathrm{m})$ and interstriae continuing onto the mantle. Several interstriae bifurcate. Every third to fifth interstria is thicker (shadow-line) and has externally the opening of the marginal fultoportulae (internally the short tubules have two satellite pores in a circumferential direction). Usually one (sometimes two) rimoportula opening is situated on the valve face at the end of a shortened stria, internally with a sessile to slightly stalked labium.

Cyclotella radiosa is a pelagic species of lakes and lowland rivers; it prefers eutrophic conditions with higher conductivity and alkalinity but can also be found in mesotrophic waters. It has a medium frequency in Hungarian running waters with a $13 \%$ occurrence rate (Fig. 16 F).

Discostella Houk et Klee 2004

Discostella pseudostelligera (Hustedt) Houk et Klee 2004 (Figs. 17 A-C)

The species was first described by HustedT (1939) from Rivers Ems as Cyclotella pseudostelligera. HouK and KLEE (2004) transferred it to Discostella genus as D. pseudostelligera.

Frustules are cylindrical $4-10 \mu \mathrm{m}$ in diameter. The valve face is nearly flat (the central part sometimes slightly domed or depressed), weakly silicified (Fig. 17 A). The marginal area has radial interfascicles $(18-20 / 10 \mu \mathrm{m})$ which can be branched. Fascicles have usually two rows of areolae. Central area can be with or without a star-shaped (stellate) structure. There is a zone with no ornamentation between the short striae and the star-like pattern. The valve mantle has 2-3 lines of areolae. The marginal openings of fultoportulae are located on every $\left(2^{\text {nd }}\right) 3^{\text {rd }}$ to $6^{\text {th }}$ stria and characterized by a unique elongated tube (the end of these tubes can be flat or bifurcated). The internal openings of the marginal fultoportulae are situated between costae and surrounded by 2 satellite pores. There is no valve face fultoportula. One rimoportula is situated in the mantle area close to the valve end between costae, at slightly lower position then the marginal fultoportulae (Fig. 17 B), with a sessile labium. Among the costae alveolar chambers can be seen.

Discostella pseudostelligera is a cosmopolitan species, found in lakes or lowland rivers. It prefers nutrient-rich waters but it has been found in oligotrophic to eutrophic waters. It is the second most frequently found species in Hungarian running waters with a $53 \%$ occurrence rate (Fig. $17 \mathrm{C}$ ).

Discostella stelligera (Cleve et Grunow) Houk et Klee 2004 (Figs. 17 D-F)

The species was described from Lake Rotoaira (North Island, New Zealand) by GRUNOw in CLEVE (1881) as Cyclotella meneghiniana var. stellulifera, and then raised to Cyclotella stelligera by CLEVE and GRUNOW in VAN HEURCK (1882). HouK and KLEE (2004) transferred it to Discostella genus as D. stelligera.

Frustules are circular, disk-shaped, $5-40 \mu \mathrm{m}$ in diameter. The centre of the valve face is concave or convex (Fig. $17 \mathrm{D}$ ). The convex central area always displays a star-shaped (stellate) structure usually composed of elongated alveoli, open to the valve inside and with an areolate outer layer (1-2 lines of areolae). The concave central area always lacks alveoli (so the central area is a large hyaline part in inside view); has a not well defined stellate pattern externally, consisting of radially arranged costae. Marginal area is with regular radial interstriae (internally thick costae), 9-16/10 $\mu \mathrm{m}$ (Fig. $17 \mathrm{E}$ ). Among the costae there 

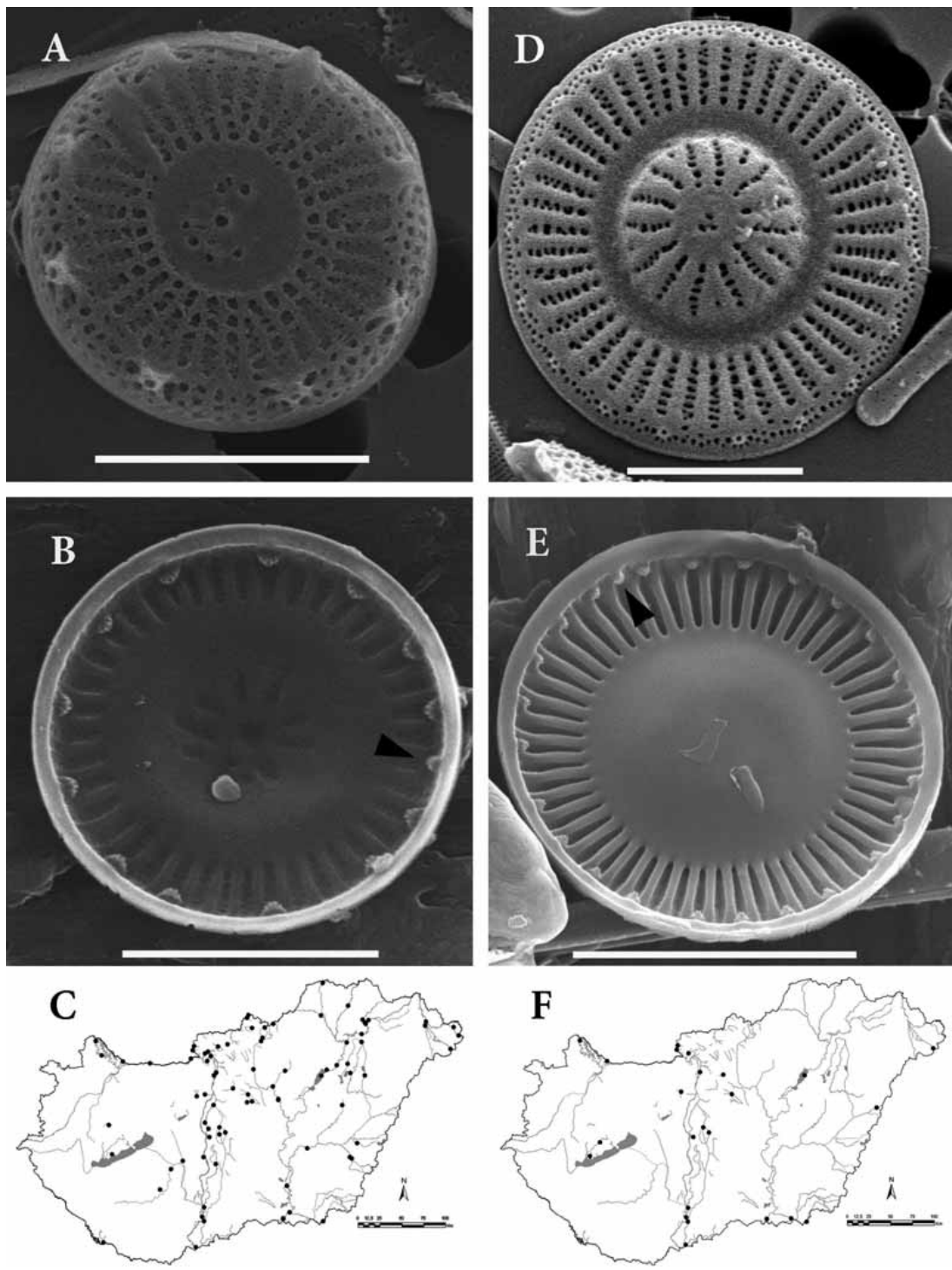

Fig. 17. A-B - Discostella pseudostelligera outside and inside view. D-E - D. stelligera outside and inside view; C: - distribution of D. pseudostelligera; F - D. stelligera. Scale bar $10 \mu \mathrm{m}$ (E) and $5 \mu \mathrm{m}(\mathrm{A}, \mathrm{B}, \mathrm{D})$.

are well-developed alveolar chambers. The mantle has 1 line of areolae. Marginal fultoportulae are located on every second, third or fourth stria. The internal openings of the marginal fultoportulae are surrounded by 2 satellite pores. The external openings are structured as very short tubes or pores, surrounded by silicified rings (tubular structure). There is no valve face fultoportula. One rimoportula occurs at the valve edge between two costae (a little bit higher than the fultoportulae), internally with a sessile labium in the ring of marginal fultoportulae, externally with a simple pore between two costae. 
Discostella stelligera is a cosmopolitan species, it can be found in lakes or lowland rivers. It prefers oligotrophic, mesotrophic waters. It has a medium frequency in Hungarian running waters with a $17 \%$ occurrence rate (Fig. 17 F).

Stephanocostis Genkal et A. E. Kuzmina 1985.

Stephanocostis chantaicus Genkal et A. E. Kuzmina (Figs. 18 A, B)

GENKAL and KUZMINA (1985) described this species from Lake Khantaiskoye in Siberia. CASPER and SCHEFFLER (1986) described this species as Pleurocyclos stechlinensis from the oligotrophic Lake Stechlin, Brandenburg, Germany; the description of GENKAL and KUZMINA
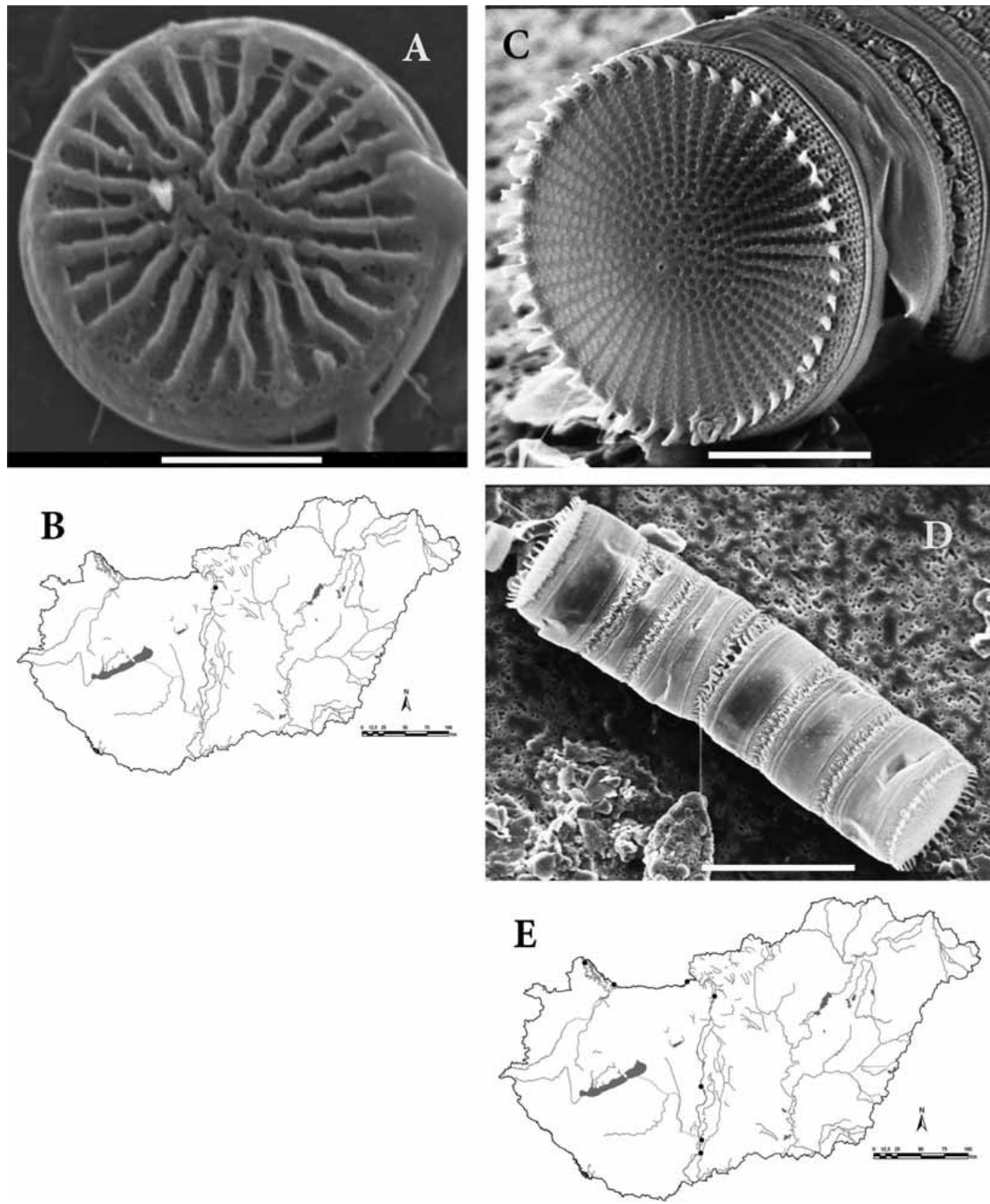

Fig. 18. A - Stephanocostis chantaicus outside view. C-D - Stephanodiscus binderanus outside view and chain; B - distribution of S. chantaicus; E - S. binderanus. Scale bar $10 \mu \mathrm{m}$ (D), $3 \mu \mathrm{m}$ (C) and $2 \mu \mathrm{m}(\mathrm{A})$. 
has nomenclatural priority. SCHEFFLER and Morabito (2003) provided very good SEM illustrations of this Stephanocostis from the plankton of Lago di Como (Italy) and Stechlinsee (Germany).

Frustules are cylindrical, solitary or in short chains, 3.5-8.0 $\mu \mathrm{m}$ in diameter. The valves are flat or, rarely, concentrically undulated. The characteristic feature of this species is the strongly elevated interstriae on the valve face (Figs. $18 \mathrm{~A}$ ), they can be branched and become a little bit wider near the margin. Some of them are shorter and do not reach the centre of the valve face. The areolae between the interstriae are irregularly arranged. There is one areola in striae near the centre and 3-4 close to the margin. Position of central fultoportula is eccentric (with three satellite pores), difficult to differentiate among the areolae in the central part. The small external openings of the marginal fultoportulae are slightly elevated. One rimoportula is situated on an interfascicle near the margin.

Stephanocostis chantaicus has been found in different mesotrophic lakes and rivers, sometimes as an abundant species. It is rare in Hungarian running waters with a $1 \%$ occurrence rate (Fig. 18 B).

\section{Stephanodiscus Ehrenberg 1846 \\ Stephanodiscus binderanus (Kützing) Willi Krieger 1927 (Figs. 18 C-E)}

This species was described by KÜTZING (1844) as Melosira binderana, and was transferred to the genus Stephanodiscus by KRIEGER (1927) on the basis of its frustular morphology. A detailed description about the SEM and TEM morphology of Stephanodiscus binderanus and S. binderanus var. oestrupii was published by Round (1972) and GENKAL (1997).

The barrel-like frustules form filaments (strong chains; Fig. $18 \mathrm{C}$ ). Valve is flat, 4-24 $\mu \mathrm{m}$ in diameter. Radial rows of areolae form striae, between them distinct interfascicles are situated. Number of areolae 2 (3) near the valve margin, 12-13/10 $\mu \mathrm{m}$. There are characteristic spines at the end of each interstria (Fig. 18 D). Spines are bifurcated and they connect the frustules together. Marginal fultoportulae with three satellite pores have an external tube. A single fultoportula is situated with two satellite pores on the valve face near the centre (it is not seen well in many cases). The internal openings of areolae have domed cribra, characteristic for many Stephanodiscus species. The girdle region consists of two short bands adjacent to the two valve mantles and intermediate wider band(s). The girdle region is delicate and often collapses. The connection between valves by spines is so strong that frustules can more easily break at valve mantle - girdle junction than between two valves.

Stephanodiscus binderanus is a cosmopolitan species and has been recorded from many rivers and lakes with different trophic status. It is a rare species in Hungarian running waters with a $1 \%$ occurrence rate (Fig. $18 \mathrm{E}$ ).

\section{Stephanodiscus hantzschii Grunow in Cleve and Grunow 1880 (Figs. 19 A-F)}

This species has been variously interpreted and illustrated by several authors since its description by GRUNOW in CLEVE and GRUNOW (1880).

Frustule is cylindrical; valve circular, almost flat, with moderately sloped mantle margins, 5-30 $\mu \mathrm{m}$ in diameter. Valve face consisting of areolae arranged in striae separated by distinct interstriae. Interstriae subtended by a well-developed spine. There is no valve face fultoportula. Marginal fultoportulae with three satellite pores occur below every third to fifth spine. Between the marginal fultoportulae a rimoportula is located centripetally from 

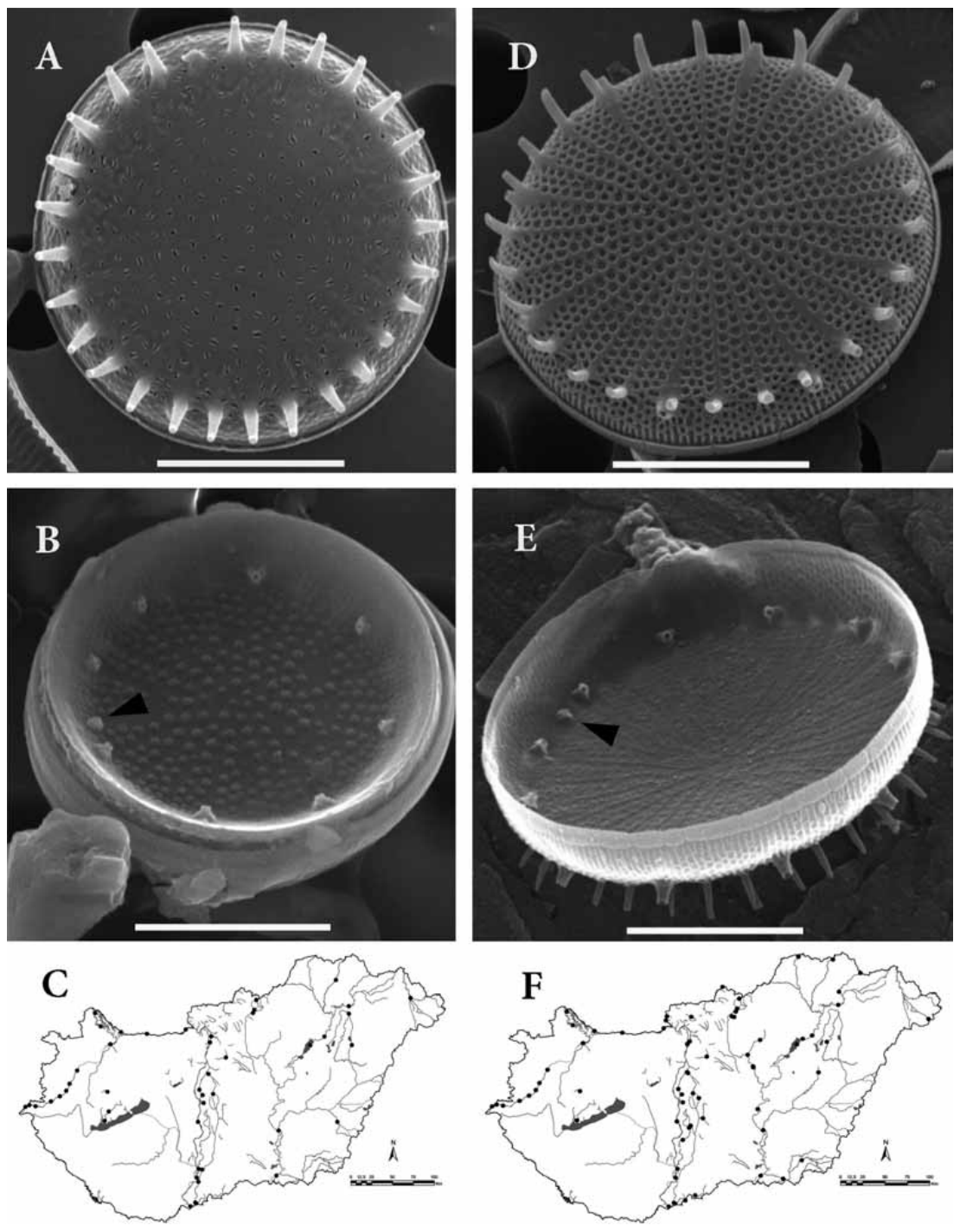

Fig. 19. A-B - Stephanodiscus hantzschii f. hantzschii outside and inside view. D-E - S. hantzschii f. tenuis outside and inside view; C - distribution of S. hantzschii f. hantzschii, F: S. hantzschii f. tenuis. Scale bar $5 \mu \mathrm{m}(\mathrm{A}, \mathrm{B}, \mathrm{D}, \mathrm{E})$.

the level of the spine insertion. The internal opening of the rimoportula has a well developed labium and the external opening is an elongated tube (frequently not seen well), somewhat similar to the spines in appearance. Valve ornamentation occurs in two distinct forms (f. hantzschii and f. tenuis), with occasional intergrades between them.

The areolae of the valve face are arranged in biseriate striae near the margin and becoming uniseriate near the centre. There are 8-10 striae in $10 \mu \mathrm{m}$ near the valve margin, separated by a wide and distinct interstria (Fig. 19 A). Number of areolae 18-25 in 10 $\mu \mathrm{m}$. Valves frequently appear strongly silicified under EM. Areolae of valve face with domed cribra are 
variously formed (Fig. 19 B), depending on the degree of silicification, they can be circular, slit-like or partially occluded. Areolae of valve mantle are much finer and are often arranged in line.

\section{Stephanodiscus hantzschii f. tenuis (Hustedt) Håkansson et Stoermer 1984 (Figs. 19 D-F)}

HustedT (1957) described Stephanodiscus tenuis with a fine silicified valve resembling to $S$. hantzschii. Based on a detailed observation of the type material of $S$. hantzschii, HÅKANSSON and STOERMER (1984) transferred S. tenuis to S. hantzschii as its forma.

Areolae of the valve face are arranged in multiseriate (3-5) striae near the valve margin, becoming uniseriate near the centre (Figs. 19 D, E). Striae 8-10/10 $\mu \mathrm{m}$ near the valve margin and separated by a thin but distinct interstria. Number of areolae $25-35 / 10 \mu \mathrm{m}$. The striae and interstriae can become sinuous towards the valve centre. In the centre an annulus, a rosette-like structure is differentiated. There are long spines on each interstria at the valve margin (Fig. 19 D).

Stephanodiscus hantzschii is a cosmopolitan species, recorded in rivers and lakes with different trophic levels and halobity. Stephanodiscus hantzschii f. hantzschii has a medium frequency in Hungarian running waters with a $24 \%$ occurrence rate (Fig. 19 C), S. hantzschii f. tenuis is frequent with a $37 \%$ occurrence rate (Fig. 19 F).

\section{Stephanodiscus minutulus (Kützing) Cleve et J. D. Möller 1882 (Figs. 20 A-C)}

This species was described as Cyclotella minutula by KüTZING (1844) and was transferred by CLEVE and MöLLER (1882) to the genus Stephanodiscus as S. minutulus. Important data were published in the papers of HÅKANSSON (1986, 2002), GENKAL and HÅKANSSON (1990).

Frustule is short, cylindrical, $4-12 \mu \mathrm{m}$ in diameter (Fig. $20 \mathrm{~A}$ ). The valve face is flat or slightly concave or convex. There are radial rows of areolae (striae), which are disorganized in the centre, then uniseriate and multiseriate (2-3) near the margin. The central area with relatively large, usually round areolae, is characteristic but depending on degree of valve silicification slit-like or elongated openings of areolae occur, too. The valve mantle is very shallow, about 2 to 3 areolae at most. Short, solid spines are situated on each interstria at the margin. Just below the spines, the round openings of marginal fultoportulae with two satellite pores can be seen on each second to fifth interstria and a single rimoportula with small sessile labium among them (Fig. 20 B). A single valve face fultoportula with two satellite pores is visible towards the centre; its external opening is elevated a little. The internal valve face is very characteristic with domed cribra of areolae.

Stephanodiscus minutulus is a cosmopolitan species; it has been recorded as frequent and abundant in rivers and shallow lakes with different trophic status. It is a characteristic species in the River Danube first of all during the cold period (from November to April). It is a frequent species in Hungarian running waters with a $44 \%$ occurrence rate (Fig. 20 C).

Stephanodiscus neoastraea Håkansson et B. Hickel 1986 emend. Casper, Scheffler et Augsten 1992 (Figs. 20 D-F)

Stephanodiscus neoastraea was described by HÅKANSSON and HICKEL (1986) from the Bornhöveder See (Germany). CASPER et al. (1992) made an amended description of the species, and CASPER and KLEE (1992) made a clear differentiation of S. rotula and S. neoastraea based on the valve face fultoportula arrangement HÅKANSSON (2002) confirmed the absence of valve face fultoportula in the latter species. GENKAL (2009) considered S. agassizensis, S. heterostylus and $S$. maximus as synonyms of $S$. neoastraea, and defined its autecology as a 

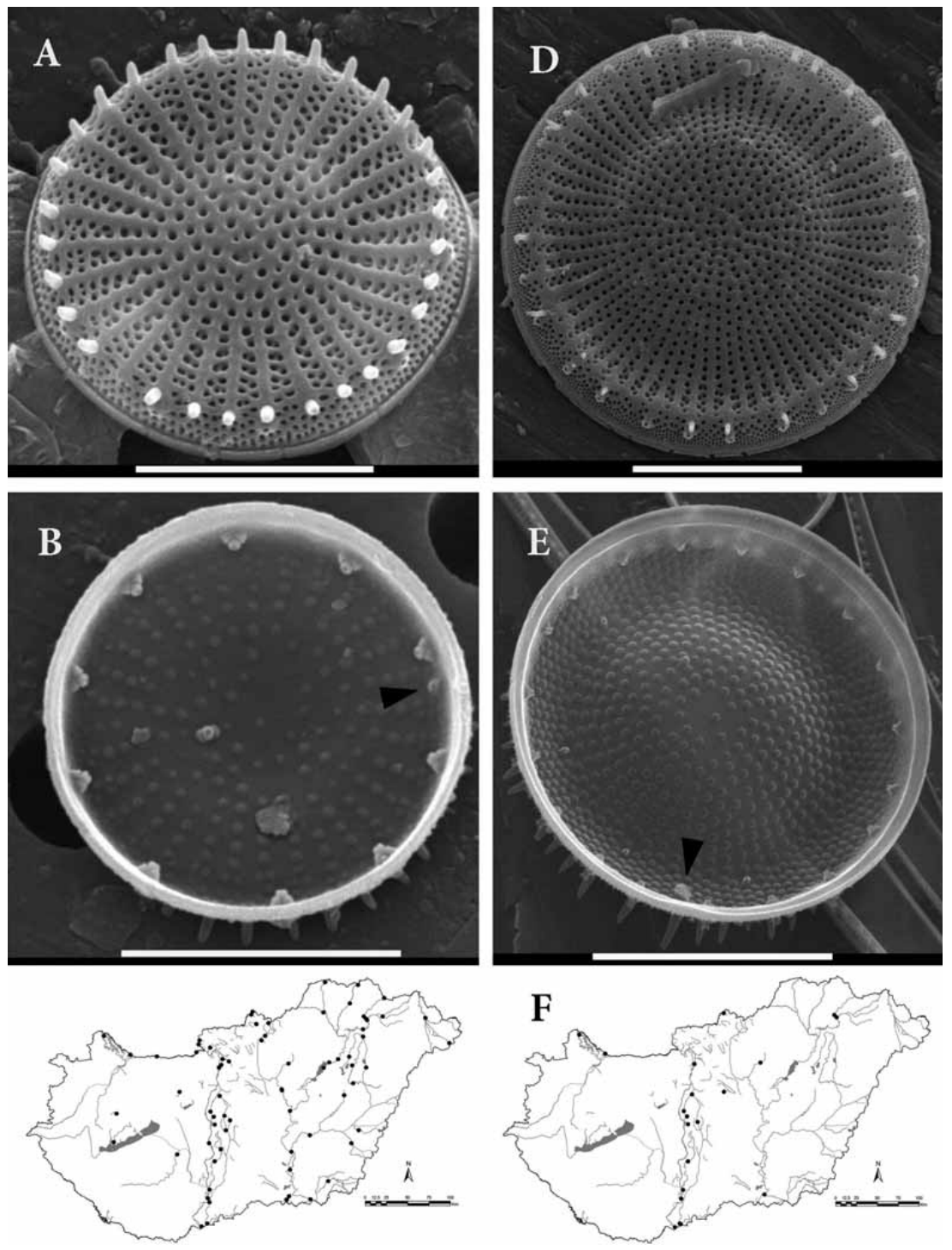

Fig. 20. A-B - Stephanodiscus minutulus outside and inside view. D-E - S. neoastraea outside and inside view; C - distribution of S. minutulus; F - S. neoastraea. Scale bar $10 \mu \mathrm{m}(\mathrm{D}, \mathrm{E})$ and $5 \mu \mathrm{m}(\mathrm{A}, \mathrm{B})$.

freshwater-brackish water, widespread planktonic species, present in spring-autumn at water temperatures of $10-24{ }^{\circ} \mathrm{C}$, salinity up to $7.5 \%$ o, transparency $50-90 \mathrm{~cm}$, and $\mathrm{pH} 7.6-8.2$.

Frustules are circular, iso- or heterovalvate, solitary or in short chains. The centre of the valve face is concave or convex (Fig. 20 D), 11-54 $\mu \mathrm{m}$ in diameter. Areolae with domed cribra arranged in fascicles. These fascicles are biseriate (rarely triseriate) at the edge of the valve face and uniseriate towards the centre, interfascicles $8-11 / 10 \mu \mathrm{m}$. The areolation of the valve centre can be irregular or the fascicles end in a rosula (annulus). Relatively long 
spines are arranged irregularly on every 2 nd -4 th interfascicle at the valve edge. There are marginal fultoportulae on the mantle below the spines on 1-3 interstriae. Their external opening has a short tube, internally with three satellite pores (Fig. $20 \mathrm{E}$ ). Valve face fultoportulae $0-5$, on convex valves they are on the central part of the valve face (Fig. $20 \mathrm{D}$ ), while on concave valves they are near the marginal part where the fascicles become biseriate (Fig. 20 E). Their external openings are slightly elevated and have two satellite pores. A single rimoportula is visible among the marginal fultoportulae with a long external tube and a well-developed stalked labium.

Stephanodiscus neoastraea can be found in eutrophic lakes and lowland rivers, but it has also been found in the oligotrophic Lake Stechlin, Germany. It has a medium frequency in Hungarian running waters with a $13 \%$ occurrence rate (Fig. 20 F).

\section{Stephanodiscus vestibulis Håkansson, E. C. Theriot et Stoermer 1986 (Figs. 21 A-C)}

HÅKANSSON et al. (1986) described Stephanodiscus vestibulis from a man-made canal »Lazy Lagoon«, connected with the eutrophic West Okoboji Lake (Dickinson Country, Iowa, USA).

Frustules are cylindrical, $4-11 \mu \mathrm{m}$ in diameter. The centre of the valve face is concave or convex. From the central area uniseriate rows of areolae $(14-30 / 10 \mu \mathrm{m})$ run towards the valve face/mantle junction, becoming biseriate after the central elevation/depression (Fig. $21 \mathrm{~A}$ ). Internally, the areolae are covered by domed cribra. There is a single valve face fultoportula on the central area with an external thickened opening and internally with three satellite pores (Fig. 21 B). Every interfascicle bears a solid spine on the valve face/mantle junction. The mantle has 3-4 lines of areolae. The marginal fultoportulae are located on every third-fourth interfascicle. The external opening of fultoportulae is hidden by a vestibule (a porch-like structure). Internally, the short tubules of fultoportulae are surrounded by three satellite pores. One rimoportula with a tubular-like extension is in the ring of spines, internally with a sessile, slit-like labium, externally with a longer tube than the spines.

Stephanodiscus vestibulis was recorded from eutrophic freshwaters of western North America, Japan and Korea; it is a probably a widespread cosmopolitan species, invasive in Europe. It is actually a scarce species in Hungarian running waters with a $6 \%$ occurrence rate (Fig. $21 \mathrm{C}$ ).

\section{COSCINODISCALES}

\section{Hemidiscaceae}

Actinocyclus Ehrenberg 1837

Actinocyclus normanii (W. Gregory ex Greville) Hustedt 1957 (Figs. 21 D-F)

The species was described by GREGORY Ex GREVILLE (1859) as Coscinodiscus normanii and was transferred to Actinocyclus by HusteDT (1957) as A. normanii var. subsalsus (Juhlin-Dannfelt) Hustedt. KISS et al. (1990) suggested that the two forms of this species (f. normanii and f. subsalsa) have no taxonomical value and should not be treated as separate taxa.

The frustule is drum shaped; the valve face is flat or slightly concave or convex. The diameter is $13-66 \mu \mathrm{m}$, the length of the pervalvar axis $11-33 \mu \mathrm{m}$. The valve face has a characteristic areola pattern. Areolae are positioned into sectors (Fig. 21 D). The sectors are delimited on both sides by a single row of areolae, which are radial and reach the centre of the valve face. The rows of areolae within a sector are parallel to the delimiting row of areo- 

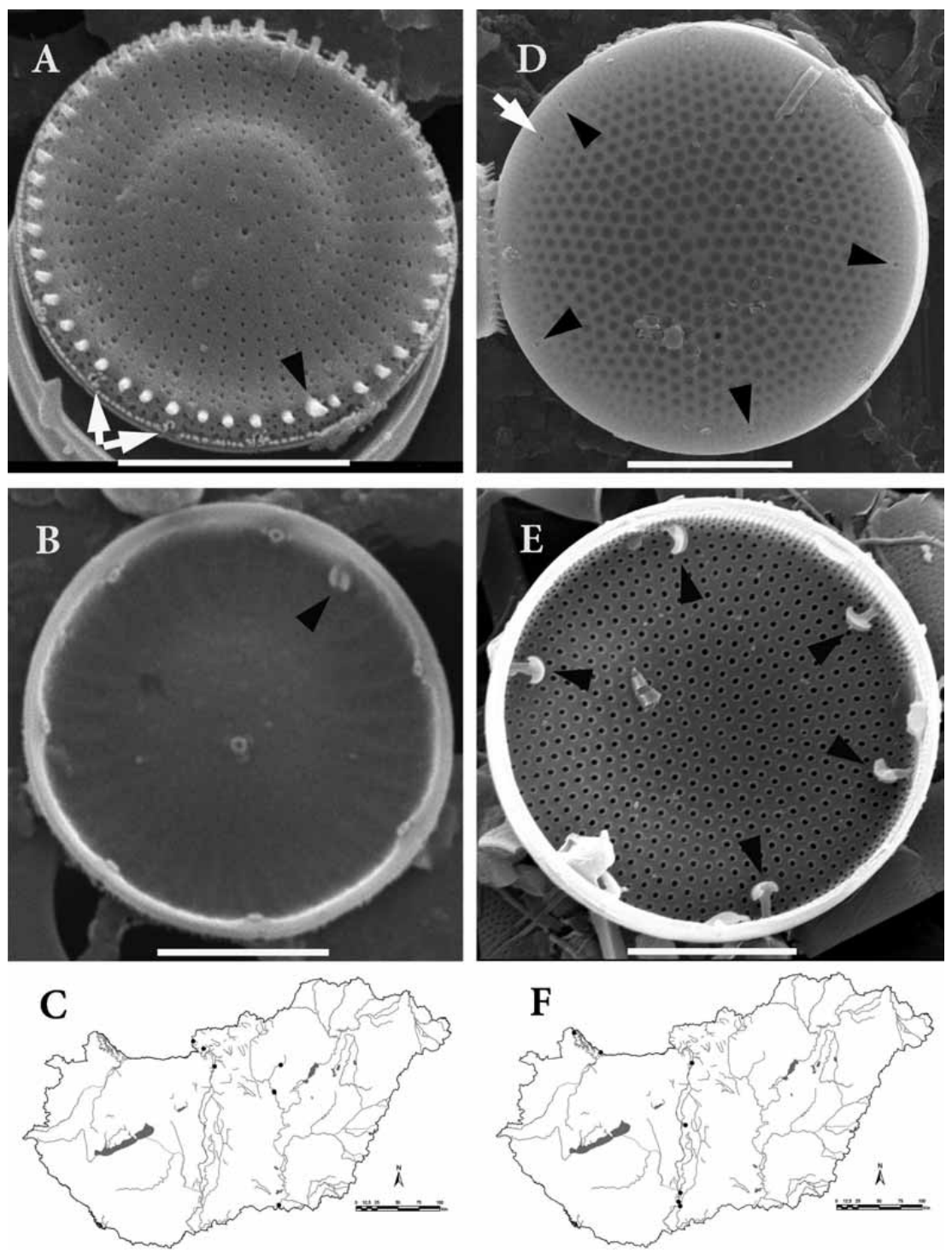

Fig. 21. A-B - Stephanodiscus vestibulis outside and inside view. D-E - Actinocyclus normanii outside and inside view (pseudonodulus white arrow). $\mathrm{C}$-distribution of S. vestibulis; F: - A. normanii. Scale bar $10 \mu \mathrm{m}$ (D, E), $5 \mu \mathrm{m}$ (A) and $2 \mu \mathrm{m}$ (B).

lae and gradually decrease in length. On the valve face the areolae are occluded externally by a cribrum with very tiny pores and they are opened internally with a well-developed foramen (Fig. $21 \mathrm{E}$ ); 6-12 areolae in $10 \mu \mathrm{m}$ on the valve face and 11-22 on the valve mantle. The number of areolae depends on the diameter; it is higher on small valves $(15-25 \mu \mathrm{m})$ and lower on large valves $(50-66 \mu \mathrm{m})$. Areolae run down straight on the valve mantle, parallel to the pervalvar axis. The external openings (pores) of the rimoportulae are clearly visible on the curved outer surface of the mantle; they have an elongated neck and a large labium. The 
Kiss K. T., KlEE R., Ector L., Ács É.

pseudonodulus is located above the openings of the rimoportulae (Fig. $21 \mathrm{D})$. It has a slight depression and a larger opening than those of the rimoportulae. The most typical morphological feature of the inner part of the valve is the ring of rimoportulae, 3-11 in number, depending on the diameter.

Actinocyclus normanii has been recorded from several eutrophic lakes and rivers with different halobity. Its increase during the last decades could be the result of eutrophication (KISS et al. 1990). Actinocyclus normanii is considered a warm stenothermic species because its density is high in the summer. It might be an invasive species. It is a rare species in Hungarian running waters with a $3 \%$ occurrence rate (Fig. $21 \mathrm{~F}$ ).

\section{Discussion}

During this study we examined altogether 107 different watercourses. Among them the largest was the River Danube from which more than 100 samples were analysed by EM from 10 Hungarian sampling sites. Only one sample was analysed from creeks, which were the smallest streams analysed in this study. There were also channels out flowing from rivers or connecting different rivers. Usually they are slowly flowing channels of different size.

In total, 41 centric taxa, belonging to 11 genera, were found during this study. The average taxon number found in a single watercourse was 7 , the maximum 40 and the minimum 1. Cyclotella meneghiniana was the most frequently encountered species (more than $60 \%$ of all sites, Fig. 22). The following 12 taxa were found in more than $20 \%$ of sites (between 20-53\%): Aulacoseira granulata, Conticribra weissflogii, Cyclostephanos dubius, C. invisitatus, Cyclotella atomus var. atomus, C. atomus var. gracilis, C. ocellata, Discostella pseudostelligera, Melosira varians, Stephanodiscus hantzschii f. hantzschii, S. hantzschii f. tenuis, S. minutulus. Eight taxa were found in 5-10\% of the investigated sites (Aulacoseira

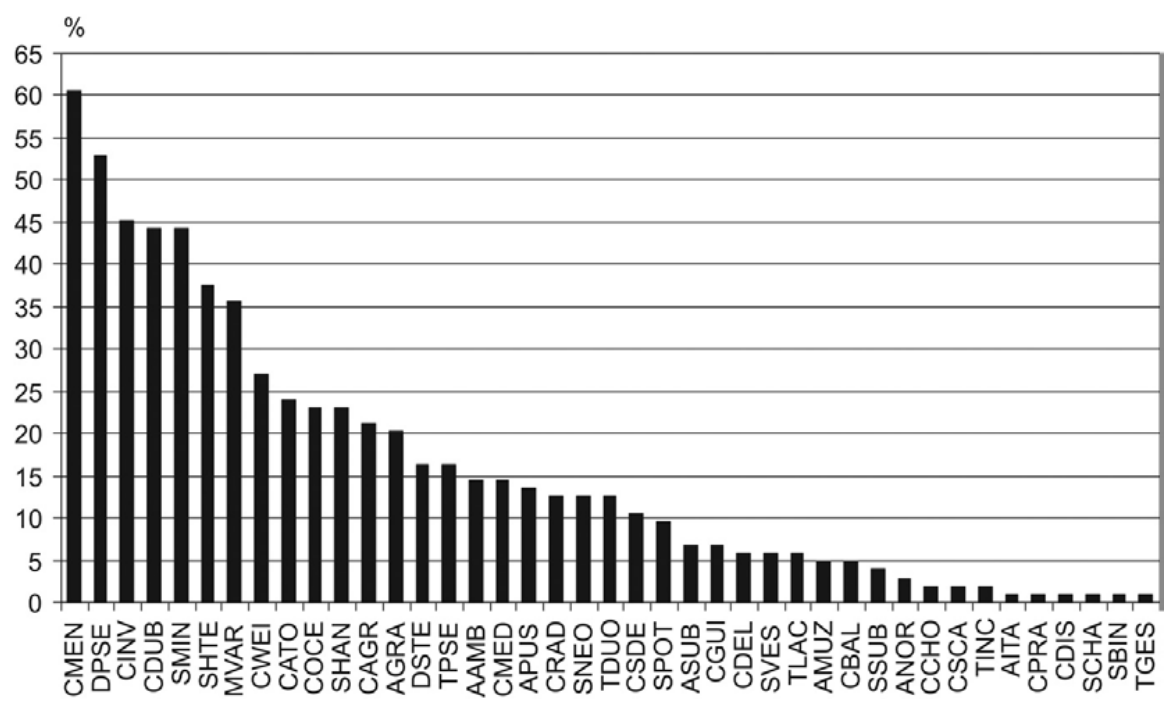

Fig. 22. The occurrence frequency of centric diatom species in the investigated Hungarian rivers, expressed as the percentage of all sampling sites in this study where the given species occurred (abbreviations of species names correspond to the OMNIDIA program). 
aff. muzzanensis, A. subarctica, Conticribra guillardii, Cyclotella balatonis, C. delicatula, Skeletonema potamos, Stephanodiscus vestibulis, Thalassiosira lacustris) and 6 taxa were found in only one site (Aulacoseira italica, Cyclotella distinguenda, C. praetermissa, Stephanocostis chantaicus, Stephanodiscus binderanus, Thalassiosira gessneri).

There is a correlation between river size (river order) and the species richness of centric diatoms (Fig. 23). The number of species in rivers increases with the size of the catchment area. There are several reasons behind this phenomenon. A large river has many affluents and they enrich the host river with their algal flora. Large rivers have more connections with lakes and many lacustrine species originate from there. They have many side arms and oxbows which are also a source of centric diatoms. Reservoirs can frequently be found on large rivers where centric diatoms can proliferate easily in the still water. There are man-made channels between rivers which can transport algae between them.

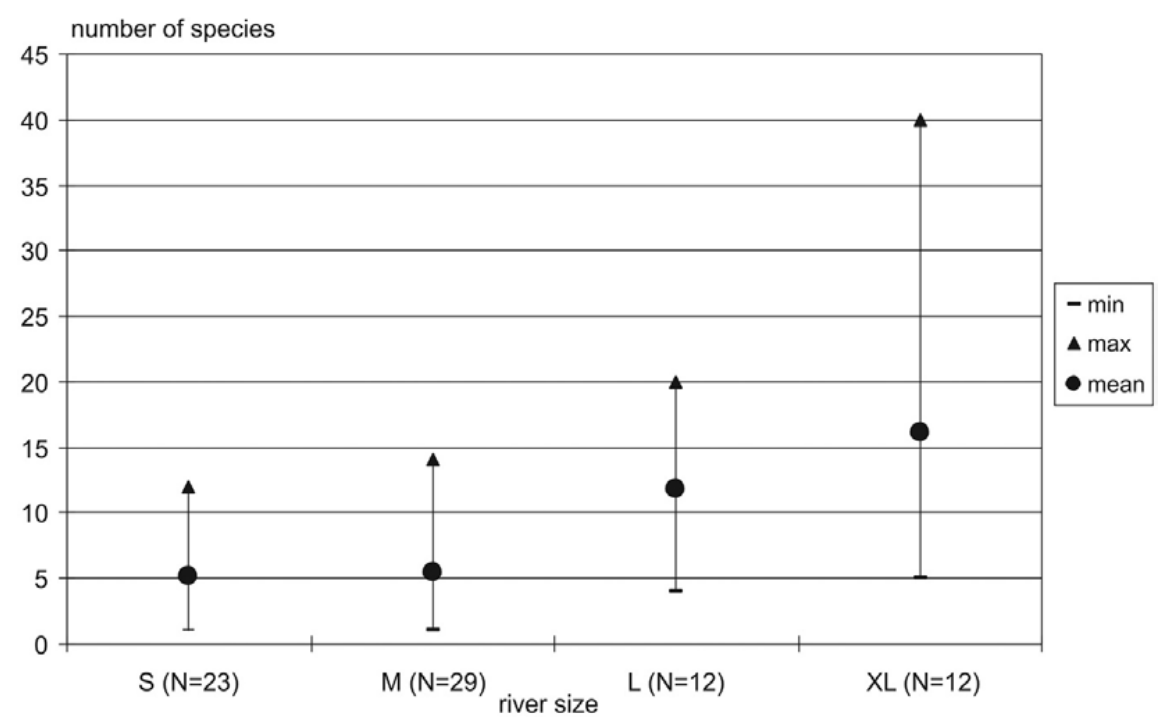

Fig. 23. Taxon numbers in different sized rivers (S: watershed $<100 \mathrm{~km}^{2}, \mathrm{M}: 100.1-1000 \mathrm{~km}^{2}, \mathrm{~L}$ : $1000.1-10000 \mathrm{~km}^{2}, \mathrm{XL}:>10000.1 \mathrm{~km}^{2}$ ).

We believe that riverine species can be found among the frequently and moderately frequently occurring centric species (Fig. 22) but there are also riverine species among the rarer species, too. We consider the following species true riverine species (real potamoplanktic species, defined as living and proliferating in slowly flowing rivers with a current of about $1 \mathrm{~m} \mathrm{~s}^{-1}$ or less): Aulacoseira granulata, Conticribra weissflogii, Cyclostephanos dubius, C. invisitatus, Cyclotella atomus, C. meduanae, C. meneghiniana, Skeletonema potamos, Stephanodiscus hantzschii, S. minutulus, Thalassiosira duostra, T. pseudonana. The most abundant taxa in large rivers are among these potamoplanktonic species. Here are a few examples from the river Danube: S. minutulus is one of the most abundant species in the cold season (early spring and late autumn). Cyclostephanos invisitatus is abundant from April to late September; S. hantzschii f. tenuis in the summer and autumn. We consider Skeletonema potamos a warm stenothermic species, it may be the most abundant Centrales 
species during the summer. Cyclotella atomus, C. meduanae, C. meneghiniana, T. pseudonana have medium abundance from early May to late September (KISs 1984, 1987, 1988; KISS and GenKal 1993, 1996; KISS et al. 1994).

There are several periphytic species living in rivers which are washed out from the periphyton, like most of the Aulacoseira species and Melosira varians. Several lacustrine species were found during this study in rivers and channels, like Actinocyclus normanii, Cyclotella balatonis, C. distinguenda, C. ocellata, C. praetermissa, C. radiosa, Discostella pseudostelligera, D. stelligera. Among these species, D. pseudostelligera can be abundant in summer time; A. normanii was abundant in summer at the end of $1980^{\text {th }}$ and it became rare during the past three decades (KISS and NAUSCH 1988, KIss et al. 1990). Cyclotella choctawhatcheeana is a brackish water species and probably has a salt lake origin in Hungarian rivers. There are several salt lakes in Transylvania (Romania) and these lakes could be the origin of this species (further studies can prove this hypothesis).

It is important to evaluate centric diatoms of Hungarian rivers from a nature conservation point of view. Hungary does not have an accepted, comprehensive Red List that includes centric diatoms. The demand for such a Red List has already been acknowledged, however, targeted research has only just started (Ács et al. 2002, 2004; SzABó et al. 2004, 2005; KISS 2005, NÉMETH 2005, KISS and ÁCS 2009). The first, internationally recognised red list of diatoms was published by LANGE-BERTALOT and STEINDORF (1996) about the freshwater species of Germany. This list includes several hundred species from the ones that are at the brink of extinction to the ones that are not endangered momentarily. Recognising the nature conservation value of algae, another comprehensive list has been published in Slovakia, which includes algae and cyanobacteria as well (HiNDÁK and HindáKOvÁ 2001). In this publication, the authors mainly list rare species from Slovakia, moreover species that have been described from Slovakia. For this reason, there are only a few centric species in this list, which also occur in Hungary.

It has to be emphasised in connection with algological red lists, that rare, conservationally valuable algae - like any other microscopical and macroscopical aquatic organisms - can only be protected by protecting the whole lake and its nearest surroundings, its catchment area. Also in the case of rivers, a selected part of the catchment area has to be treated as nature conservation area.

Several taxa were found in Hungarian rivers that are valuable or potentially valuable from a nature conservation perspective, based on LANGE-BERTALOT and STEINDORF (1996), SzABó et al. (2004), KISS (2005), NÉMETH (2005), KISS and ÁCS (2009). Several of the rare species could be listed in some future Hungarian Red List of algae. These are the following:

Endangered taxa: Cyclotella choctawhatcheeana, C. distinguenda, Stephanocostis chantaicus.

Vulnerable taxa: Aulacoseira subarctica, Conticribra guillardii, Cyclotella delicatula, Thalassiosira gessneri, T. incerta, T. lacustris.

Taxa with decreasing stocks: Actinocyclus normanii, Aulacoseira pusilla, Cyclotella scaldensis, C. praetermissa, Skeletonema subsalsum, Stephanodiscus binderanus.

Taxa not yet classified: Aulacoseira pusilla, Cyclostephanos invisitatus, Cyclotella atomus var. gracilis, Cyclotella meduanae, Cyclotella scaldensis. 


\section{Acknowledgements}

This study was supported by Hungarian National Science Foundation (ОткA к 68327, and partly by KтіA-OTKA 80140). We gratefully acknowledge Dr. Eduardo A. Morales (Universidad Católica Boliviana San Pablo, Cochabamba, Bolivia) for constructive comments on the manuscript. We would like to thank Katalin E. Szabó-Taylor for language correction of the manuscript.

\section{References}

Ács É., SzABó K., Kiss K. T., 2002: Nature conservation oriented algal biodiversity monitoring investigations in the main arm and some dead arms of the River Tisza I. Benthic diatoms. Limnological Reports 34, 111-120.

Ács, É., SzABó, K., Kiss, Á. K., Tóth, B., ZÁraY, Gy., Kiss, K. T., 2006: Investigation of epilithic algae on the River Danube from Germany to Hungary and the effect of a very dry year on the algae of the River Danube. Archiv für Hydrobiologie Suppl. Large Rivers $16,389-417$.

Ács É., Szabó K., Tóth B., KIss, K. T., 2004: Investigation of benthic algal communities, especially diatoms of some Hungarian streams in connection with reference conditions of the Water Framework Directives. Acta Botanica Hungarica 46, 225-278.

AgardH, C., 1827: Aufzälung einiger in den östereichischen Länden gefundenen neuen Gattungen und Arten von Algen neben ihrer Diagnostik und beigefügten Bemerkungen. Flora 10, 626-646.

Aké Castillo, J., Meave del Castillo, M. E., Hernández-Becerril, D. U., 1995: Morphology and distribution of species of the diatom genus Skeletonema in a tropical coastal lagoon. European Journal of Phycology 30, 107-115.

Alverson, A. J., Beszteri, B., Julius, M. L., Theriot, E. C., 2011: The model marine diatom Thalassiosira pseudonana likely descended from a freshwater ancestor in the genus Cyclotella. BMC Evolutionary Biology 11, 125.

ANONYMOus, 1975: Proposals for a standardization on diatom terminology and diagnoses. Nova Hedwigia Beih. 53, 323-354.

Belcher, J. H., Swale, E. M. F., 1977: Species of Thalassiosira (Diatoms, Bacillariophyceae) in the plankton of English rivers. British Phycological Journal 12, 291-297.

Belcher, J. H., Swale, E. M. F., 1986: Species notes on some small Thalassiosira species (Bacillariophyceae) from the plankton of the Lower Thames and other British estuaries (identified by transmission electron microscopy). British Phycological Journal 21, $139-145$.

BethGE, H., 1928: Über die Kieselalge Skeletonema subsalsum (A. Cleve) Bethge. Berichte der Deutschen Botanischen Gesellschaft 46, 340-347.

BRÉBISSON, A., 1838: Considération sur les diatomées et essai d'une classification des genres et des espèces appartenant à cette famille. Brée l' Ainé Imprimeur-Libraire, Falaise, 1-22.

BudZYŃSKa, A., WoJTAL, A. Z., 2011: The centric diatom Puncticulata balatonis (Pantocsek) Wojtal et Budzyńska, comb. nov., in the plankton of eutrophic-hypertrophic Rusałka Lake (Western Poland). Nova Hedwigia 93, 509-524. 
Kiss K. T., KlEE R., Ector L., Ács É.

Burić, Z., Kiss, K. T., Ács, É., ViličIć, D., Caput Mihalić, K., Carić, M., 2007: The occurrence and ecology of the centric diatom Cyclotella choctawhatcheeana Prasad in a Croatian estuary. Nova Hedwigia 84, 135-153.

CASPER, S. J., KLEE, R., 1992: Stephanodiscus neoastraea Håkansson et Hickel (Bacillariophyceae) aus schweizerischen, bayerischen und mecklenburgischen Seen. Limnologica $22,241-247$.

Casper, S. J., Scheffler, W., 1986: Pleurocyclos nov. gen. - a new genus within the Sceletonemaceae (Bacillariophyceae). Archiv für Protistenkunde 132, 287-298.

CASPer, S. J., SchefFler, W., 1990: Cyclostephanos delicatus (Genkal) Casper et Scheffler comb. nov. from waters in the northern part of Germany. Archiv für Protistenkunde 138, 304-312.

CAsper, S. J., Scheffler, W., Augsten, K., 1992. Stephanodiscus neoastraea Håkansson et Hickel (Bacillariophyta, Centrales) in norddeutschen Seen und Flussen. Archiv für Protistenkunde 142, 193-206.

Casper, S. J., Scheffler, W., Augsten, K., Peschke, T., 1988. Some observations on the Stephanodiscus hantzschii-group (Bacillariophyta) in waters of the GDR. III. Stephanodiscus delicatus and S. rugosus in Lake Dagow. Limnologica 19, 27-34.

Clarke, K. B., 1992: Centric diatoms in the Norfolk Broads. Microscopy 36, 692-702.

Cleve, P. T., 1881: On some new and little known diatoms. Kungliga Svenska Vetenskaps-Akademiens Handlingar 18, 1-256.

Cleve, P. T., Grunow, A., 1880: Beiträge zur Kenntnis der Arctischen Diatomeen. Kungliga Svenska Vetenskaps-Akademiens Handlingar 17, 1-121.

Cleve, P. T., Möller, J. D., 1877-1882: Diatoms (exsiccata). Upsala. 324 slides.

Cleve-Euler, A., 1912: Das Bacillariaceenplankton in Gewässern bei Stockholm, 3. Über Gemeinden des schwach salzigen Wassers und eine neue Charakterart deselben. Archiv für Hydrobiologie und Planktonkunde 7, 500-513.

Crawford, R. M., Likhoshway, Y. V., Jahn, R., 2003: Morphology and identity of Aulacoseira italica and typification of Aulacoseira (Bacillariophyta). Diatom Research $18,1-19$.

Denys, L., Muylaert, K., Krammer, K., Joosten, T., Reid, M., Rioual, P., 2003: Aulacoseira subborealis stat. nov. (Bacillariophyceae): a common but neglected plankton diatom. Nova Hedwigia 77, 407-427.

EhrenBerG, C. G., 1837: Zusatze zur Erkenntniss grosser organischer Ausbildung in den kleinsten theirischen Organismen. Abhandlungen der koniglichen Akademie der Wissenschaften zu Berlin, 151-180.

EHRENBERG, C. G., 1838: Die Infusionsthierchen als vollkommende Organismen. Ein Blick in das tiefere Leben der Natur. Leopold Voss. Leipzig

EhrenberG, C. G., 1843: Einen Nachtrag zu dem Vortrage über die Verbreitung und Einfluss des mikroskopischen Lebens in Süd- und Nord-Amerika. Abhandlungen der koniglichen Akademie der Wissenschaften zu Berlin 1, 291-445.

FryXell, G. A., Hasle, G. R., 1977: The genus Thalassiosira: Some species with a modified ring of central strutted processes. Nova Hedwigia Beihefte 54, 67-98. 
GENKAL, S. I., 1977: Method of calculation of some taxonomically important structural elements of the diatom valve from family Thalassiosiraceae Lebour emend Hasle (Bacillariophyta) (in Russian). Botanicheskii Zhurnal 62, 848-851.

GenKal, S. I., 1985. New taxa from genus Stephanodiscus Ehr. (Bacillariophyta) (in Russian). Novosti Sistematiki Nizshih Rasteniy 22, 30-32.

Genkal, S. I., 1992: Atlas of planktonic diatoms from the River Volga (in Russian). Gidrometeouzdat, Sankt-Peterburg.

GenKaL, S. I., 1997: Comparative morphological and ecological analyses of the two species of the genus Stephanodiscus (Bacillariophyta). Botanicheskii Zhurnal 82, 28-33.

GenKal, S. I., 2009: New data on the morphology, taxonomy, ecology, and distribution of Stephanodiscus agassizensis Håkansson et Hickel (Bacillariophyta). Inland Water Biology 2, 113-126.

GENKAL, S. I., HÅKANSSON, H., 1990: The problem of distinguishing the newly describing diatom genus Pseudostephanodiscus Sieminska. Diatom Research 5, 15-23.

GENKAL, S. I., KISS, K. T., 1993: Morphological variability of the diatom Cyclotella atomus Hustedt var. atomus and C. atomus var. gracilis var. nov. Hydrobiologia 269/270, 39-47.

GenKal, S. I., KuZminA, A. E., 1985: New genus and species Stephanocostis chantaicus Genkal \& Kuzmin (in Russian). Biologia Vnutrennih Vod 67, 8-10.

Genkal, S. I., Pautova, V. N., Nomokonova, V. N., Tarasova, N. G., 2008: Occurrence of Cyclotella ambigua Grunow (Bacillariophyta) in the Kuibyshev Reservoir. Inland Water Biology 1, 7-13.

Genkal, S. I., Popovskaya, G. I., 2008: Morphological variability of Cyclotella ocellata from Lake Khubsulug (Mongolia). Diatom Research 23, 75-91.

Germain, H., 1981: Flore des diatomées eaux douces et saumâtres du Massif Armoricain et des contrées voisines d'Europe occidentale. Boubée et Cie. Paris.

Gibson, C. E., Anderson, N. J., Haworth, E. Y., 2003: Aulacoseira subarctica: taxonomy, physiology, ecology and palaeoecology. European Journal of Phycology 38, 83-101.

Gibson, C. E., McCall, R. D., Dymond, A., 1993: Skeletonema subsalsum in a freshwater Irish lake. Diatom Research 8, 65-71.

Gregory, W., 1859: New forms of Diatomaceae found in the Firth of Clyde and in Loch Fyne. Quarterly Journal of Microscopical Science 7, 60-64.

GreviLLE, R. K., 1859: Descriptions of new species of British Diatomaceae, chiefly observed by the late Professor Gregory. Quarterly Journal of Microscopical Science 7, 79-86.

HÅKANSSON, H., 1986: A taxonomic reappraisal of some Stephanodiscus species (Bacillariophyta). British Phycological Journal 21, 25-37.

HÅKANSSON, H., 1989: A light and electron microscopical investigation of the type species of Cyclotella (Bacillariophyceae) and related forms, using original material. Diatom Research 4, 255-267.

HÅKAnsson, H., 1990: Cyclotella meneghiniana (Kütz.) (Bacillariophyceae), its morphology and reappraisal of similar species. Nova Hedvigia 100, 19-37. 
Kiss K. T., KLEE R., Ector L., Ács É.

HÅKAnsson, H., 1993: Morphological and taxonomic problems in four Cyclotella species (Bacillariophyceae). Diatom Research 8, 309-316.

HÅKANSSON, H., 2002: A compilation and evaluation of species in the genera Stephanodiscus, Cyclostephanos and Cyclotella with a new genus in the family Stephanodiscaceae. Diatom Research 17, 1-139.

HÅKAnsson, H., Hickel, B., 1986: Morphology and taxonomy of the diatom Stephanodiscus neoastrea sp. nov. Brithish Phycological Journal 21, 39-43.

HÅKansson, H., Stoermer, E. F., 1984: Observations on the type material of Stephanodiscus hantzschii Grunow in Cleve \& Grunow. Nova Hedwigia 39, 477-495.

HÅkansson, H., Theriot, E. C., Stoermer, E. F., 1986: Morphology and taxonomy of Stephanodiscus vestibulis sp. nov. (Bacillariophyta). Nordic Journal of Botany 6, 501-505.

Hargraves, P. E., Levandowsky, M., 1971: Fine structure on some brackish-pound diatoms. Nova Hedwigia 21, 321-332.

Hasle, G. R., 1976: Examination of diatom type material: Nitzschia delicatissima Cleve, Thalassiosira minuscula Krasske, and Cyclotella nana Hustedt. British Phycological Journal 11, 101-110.

Hasle, G. R., 1978: Some freshwater and brackish water species of the diatom genus Thalassiosira Cleve. Phycologia 17, 263-292.

HASLe, G. R., Evensen, D. L., 1975: Brackish-water and fresh-water species of the diatom genus Skeletonema Grev. I. Skeletonema subsalsum (A. Cleve) Bethge. Phycologia 14, 283-297.

Hasle, G. R, Evensen, D. L., 1976: Brackish-water and fresh-water species of the diatom genus Skeletonema. 2. Skeletonema potamos comb. nov. Journal of Phycology 12, 73-82.

Hasle, G. R., Fryxell, G. A., 1977: The genus Thalassiosira: some species with a linear areola array. Nova Hedwigia 54, 15-66.

Hasle, G. R., Heimdal, B. R., 1970: Some species of the centric diatom genus Thalassiosira studied in the light and electron microscopes. Nova Hedwigia 31, 543-581.

HASLE, G. R., LANGE, C. B., 1989: Freshwater and brackish water Thalassiosira (Bacillariophyceae): taxa with tangentially undulated valves. Phycologia 28, 120-135.

Haworth, E. Y., 1988: Distribution of diatom taxa of the old genus Melosira (now mainly Aulacoseira) in Cumbrian waters. In: Round, F. E. (ed.), Algae and aquatic environment, 138-167. Biopress, Bristol.

Haworth, E. Y., 1990: Diatom name validation. Diatom Research 5, 195-196.

Hegewald, E., HindÁKovA, A., 1997: Variabilität von einer natürlichen Population und von Klonen des Cyclotella ocellata-Komplexes (Bacillariophyceae) aus dem Gallbergweiher, Nordwestdeutschland. Archiv für Hydrobiologie, Algological Studies 86, 17-37.

HindÁK, F., HindÁKOVÁ, A., 2001: Red list of cyanophytes/cyanobacteria and algae of Slovakia. The second version (December 2001) (In Slovakian). In: Baláz, D., Marhold, K., Urban, P. (eds), Červený zoznam rastlín a živočíchov Slovenska. Ochrana Prírody 20, Suppl., 13-21.

Hohn, M. H., Hellerman, J., 1963: The taxonomy and structure of diatom populations from three eastern North American rivers using three sampling methods. Transactions of the American Microscopical Society 87, 250-329. 
Houk, V., 2003: Atlas of freshwater centric diatoms with a brief key and descriptions, 1. Melosiraceae, Orthoseiraceae, Paraliaceae and Aulacosiraceae. Czech Phycology Supplement 1, 1-27.

Houk, V., KLEE, R., 2004: The stelligeroid taxa of the genus Cyclotella (Kützing) Brébisson (Bacillariophyceae) and their transfer into the genus Discostella gen. nov. Diatom Research 19, 203-228.

Houk, V., KLEE, R., 2007: Atlas of freshwater centric diatoms with a brief key and descriptions. Part II. Melosiraceae and Aulacosiraceae (Supplement to Part I). Fottea 7, 85-255.

Houk, V., KLEe, R., TANAKA, H., 2010: Atlas of freshwater centric diatoms with a brief key and descriptions, 3. Stephanodiscaceae A, Cyclotella, Tertiarius, Discostella. Fottea 10 (Supplement), 1-498.

Hustedt, F., 1926: Thalassiosira fluviatilis nov. spec., eine Wasserblüte im Wesergebiet. Berichte der Deutschen Botanischen Gesellschaft 43, 565-567.

Hustedt, F., 1927: Die Diatomeen der interstadialen Seekreide. - In: Gams, H. Die Geschichte der Lunzer Seen, Moore und Wälder. Internationale Revue der gesamten Hydrobiologie und Hydrographie 18, 317-320.

HustedT, F., 1928: Die Kieselalgen Deutschlands, Österreichs und der Schweiz unter Berücksichtigung der übrigen Länder Europas sowie der angrenzenden Meeresgebiete. - In: Kryptogamenflora von Deutschland, Österreich und der Schweiz (L. Rabenhorst, Ed.) 7 (1). Akademische Verlagsgesellschaft Geest \& Portig K.-G., Leipzig, 273-464.

HustedT, F., 1939: Die Diatomeenfrora des Küstengebietes der Nordsee vom Dollart bis zur Elbmündung. I. Die Diatomeenflora in der Sedimenten der unteren Ems sowie auf den Watten der Leybucht, des Memmert und bei der Insel Juist. Abhandlungen des Naturwissenschaftlichen Vereins, Bremen 31, 571-677.

HustedT, F., 1952: Neue und wenig bekannte Diatomeen, 4. Botaniska Notiser 4, 366-410.

Hustedt, F., 1956: Diatomeen aus dem Lago de Maracaibo in Venezuela. In Gessner, F., VARESCHI, V. (eds), Ergebnisse der deutschen limnologischen Venezuela-Expedition 1952, 1, 93-140. Deutscher Verlag der Wissenschaften, Berlin.

HustedT, F., 1957: Die Diatomeenflora des Flußsystems der Weser im Gebiet der Hansestadt Bremen. Abhandlungen Naturwissenschaftlicher Verein Bremen 34, 181-441.

Kaštovský, J., Hauer, T., Mareš, J., Krautová, M., Bešta, T., KomáreK, J., Desortová, B., Heteša, J., Hindáková, A., Houk, V., Janeček, E., Kopp, R., Marvan, P., Pumann, P., SkÁcelová, O., Zapomelová, E., 2010: A review of the alien and expansive species of freshwater cyanobacteria and algae in the Czech Republic. Biological Invasions 12, 3599-3625.

KISs, K. T., 1984: Occurrence of Thalassiosira pseudonana Hasle et Heimdal (Bacillariophyceae) in some rivers of Hungary. Acta Botanica Hungarica 30, 277-287.

KISS, K. T., 1986: Species of the Thalassiosiraceae in the Budapest section of the Danube. Comparison of samples collected in 1956-63 and 1979-83. In: RICARD, M. (ed.), Proceedings 8 International Diatom Symposium, Paris, 1984. Koeltz Scientific Books, Koenigstein, 23-31. 
Kiss K. T., KLEE R., Ector L., Ács É.

KISS, K. T., 1987: Phytoplankton studies in the Szigetköz section of the Danube during 1981-1982. Archiv für Hydrobiologie, Algological Studies 47, 247-273.

KIss, K. T., 1988: The morphology and taxonomy of Stephanodiscus invisitatus Hohn et Hellerman (Bacillariophyceae). Archiv für Protistenkunde 135, 187-196.

KIss, K. T., 2005: Phytoplankton analysis of different water bodies in the Gemenc area from a nature conservation point of view (in Hungarian). Botanikai Közlemények 92, 85-118.

KIss, K. T., Ács, É., 2009: The algal flora of the River Bodrog. Thaiszia. Journal of Botany, Kosice 19, Suppl. 1, 99-124.

KIsS, K. T., Ács, É., KovÁcs, A., 1994: Ecological observations on Skeletonema potamos (Weber) Hasle in the River Danube, near Budapest (1991, 92 - daily investigations). Hydrobiologia 289, 163-170.

Kiss, K. T., Ács, É., Szabó, K. É., Miracle, M. R., Vicente, E., 2007: Morphological observations on Cyclotella distinguenda Hustedt and $C$. delicatula Hustedt from the core sample of a meromictic karstic lake of Spain (Lake La Cruz) with aspects of their ecology. Diatom Research 22, 287-308.

KISS, K. T., GENKAL, S. I., 1993: Winter blooms of centric diatoms in the River Danube and in its side arms near Budapest. Hydrobiologia 269/270, 317-325.

Kiss, K. T., GenKal, S. I., 1996: Phytoplankton of the Danube's reservoirs in September 1995 from Germany to Hungary. Limnologische Berichte Donau 1, 143-148.

KISS, K. T., IsERENTANT, R., Ács, É., EcTOR, L., 2002: Thalassiosira gessneri Hustedt and T. lacustris (Grunow) Hasle in the rivers Moselle (Luxembourg), Rhône, Saône (France), Danube (Hungary) and the channel Main-Danube (Germany). Archiv für Hydrobiologie, Algolological Studies 107, 17-37.

Kiss, K. T., KleE, R., Hegewald, E., 1999: Reinvestigation of the original material of Cyclotella ocellata Pantocsek (Bacillariophyceae). Archiv für Hydrobiologie, Algological Studies 93, 39-53.

KISS, K. T., KovÁcs, K., DoBler, E., 1984: The fine structure of some Thalassiosira species (Bacillariophyceae) in the Danube and the Tisza rivers. Archiv für Hydrobiologie, Algological Studies 37, 409-415.

Kiss, K. T., Le Cohu, R., Coste, M., Genkal S. I., Houk, V., 1990: Actinocyclus normanii (Bacillariophyceae), in some rivers and lakes in Europe. Morphological examinations and quantitative relations. In: Ricard, M. (ed.), Ouvrage dédié à H. Germain, 111-123. Koeltz, Koenigstein.

KISS, K. T., NAUSCH, M., 1988: Comparative investigations of planktonic diatoms of section of the Danube near Vienna and Budapest. In: Round, F. E. (ed.), Proceedings 9 International Diatom Symposium, Biopress, Bristol, 115-122.

KLEe, R., SteinBerG, C., 1987: Kieselalgen Bayerischer Gewässer - Informationsberichte (Bayerisches Landesamt für Wasserwirtschaft) 4/87, 1-218.

KobAYASI, H., KoBAyASHI, H., 1987: Fine structure and taxonomy of small and tiny Stephanodiscus (Bacillariophyceae) species in Japan 5. S. delicatus Genkal and the characters useful in identifying five small species. Japanese Journal of Phycology 35, 268-276. 
KrAmMER, K., 1991: Morphology and taxonomy of some taxa in the genus Aulacoseira Thwaites (Bacillariophyceae) II. Taxa in the A. granulata-, A. italica- and A. lirata-groups. Nova Hedwivia 52, 477-496.

Krammer, K., LANGE-Bertalot, H., 1991: Bacillariophyceae. 3. Teil Centrales, Fragilariaceae, Eunotiaceae. In: Ettl, H., Gerloff, J., Heynig, H., Mollenhauer, D. (eds), Süsswasserflora von Mitteleuropa. Gustav Fischer Verlag, Stuttgart.

KRIEGER, W., 1927: Zur Biologie des Flussplanktons. Untersuchungen über das Potamoplankton des Havelgebietes. Planzenforschungen 10, 1-66.

KÜTZING, F. T., 1844: Die kieselschaligen Bacillarien oder Diatomeen. F. Dörstermann, Nordhausen.

Lange-Bertalot, H., Steindorf, A., 1996: Rote Liste der limnischen Kieselalgen (Bacillariophyceae) Deutschland. Schriftenreihe für Vegetationskunde 28, 633-678.

Lemmermann, E., 1900: Beiträge zur Kenntnis der Planktonalgen. Berichte der Deutsche Botanische Gesellschaft 18, 24-32.

Lowe, R. L., Busch, D. E., 1975: Morphological observations on two species of the diatom genus Thalassiosira from fresh-water habitats in Ohio. Transactions of the American Microscopical Society 94, 118-123.

Lowe, R. L., CRANG, R. E., 1972: The ultrastructure and morphological variability of the frustule of Stephanodiscus invisitatus Hohn et Hellerman. Journal of Phycology 8, 256-259.

Lund, J. W. G., 1951: Contributions to our knowlegde of British Algae XII. A new planktonic Cyclotella (C. praetissima n. sp.). Notes on C. glomerata Bachmann and C. catenata Brun and the occurence of setae in the genus. Hydrobiologia 3, 93-100.

MAKAROVA, I. V., 1961: New diatom taxa of family Coscinodiscaceae from Western part of Caspian Sea (in Russian). Botaniceskie Materialy Otdela Sporovyh Rastenij Botanicheskogo Instituta Imeni V. L. Komarova, Akademii Nauk S.S.S.R. 14, 49-52.

Makarova, I. V., Genkal, S. I., Kuzmin, G. V., 1979: Thalassiosira taxa (Bacillariophyta) found in continental waters of USSR (in Russian). Botanicheskiy Zhurnal 64, 921-927.

MeIsteR, F., 1912: Die Kieselalgen der Schweiz. Beiträge zur Kryptogamenflora der Schweiz 4/1, 1-254.

MEISTER, F., 1913: Beiträge zur Bacillariaceenflora Japan. Archiv für Hydrobiologie 8, 305-312.

Muylaert, K., SABbe, K., 1996: Cyclotella scaldensis spec. nov. (Bacillariophyceae), a new estuarine diatom. Nova Hedwigia 63, 335-345.

MüLleR, O., 1903: Sprungweise Mutation bei Melosireen. Berichte der Deutschen Botanischen Gesellschaft 21, 326.

Müller, O., 1906: Pleomorphismus, Auxosporen und Dauersporen bei Melosira-Arten. Jahrbücher für wissenschaftliche Botanik 43, 49-88.

NÉMETH, J., 2005: Red list of algae in Hungary. Acta Botanica Hungarica 47, 379-417.

PANTOCSEK, J., 1901: Die Kieselalgen oder Bacillarien des Balaton. Budapest. In: Lóczy, L. (red.), Resultate der wissenschaftlichen Erforschung des Balatonsees 2, 2, 1-112. K.U.K. Hofbuchdruckerei V. Hornyánszky, Budapest. 
Kiss K. T., KLEE R., Ector L., Ács É.

Pérez, M. C., Maidana, M. I., Comas, A., 2009: Phytoplankton composition of the Ebro River estuary, Spain. Acta Botanica Croatica 68, 11-27.

PienaAr, C., Pieterse, A. J. H., 1990: Thalassiosira duostra sp. nov. a new freshwater centric diatom from the Vaal River, South Africa. Diatom Research 5, 105-111.

Prasad, A. K. S. K., Nienow, J. A., Livingston, R. J., 1990: The genus Cyclotella (Bacillariophyceae) in Choctawhatchee Bay, Florida, with special reference to C. striata and C. choctawhatcheeana sp. nov. Phycologia 29, 418-436.

Ralfs, W., 1861: Melosira. In: Pritchard, A., Archer, W., Arlidge, J. T., Ralfs, J., Williamson, W. C. (eds.), A history of Infusoria, including the Desmidiaceae and Diatomaceae, British and foreign, 820. Whittaker and co., London. http://archive.org/details/ahistoryinfusor00willgoog (Access March 25, 2012)

Ross, R., Cox, E. J., Karayeva, N. I., Mann, D. G., Paddock, T. B. B., Simonsen, R., Sims, P. A., 1979: An amended terminology for the siliceous component of the diatom cell. Nova Hedwigia 64, 513-533.

Round, F. E., 1972: Stephanodiscus binderanus (Kütz.) Krieger or Melosira binderana Kütz. (Bacillariophyta, Centrales). Phycologia 11, 109-117.

Round, F. E., 1982: Cyclostephanos - a new genus within the Sceletonemaceae. Archiv für Protistenkunde 125, 323-329.

Round, F. E., Crawford, R. M., Mann, D. G., 1990: The diatoms. Cambridge University Press.

SCHEFfleR, W., Houk, V., KLEE, R., 2003: Morphology, morphological variability and ultrastructure of Cyclotella delicatula Hustedt (Bacillariophyceae) from Hustedt material. Diatom Research 18, 107-121.

Scheffler, W., Morabito, G., 2003: Topical observations on centric diatoms (Bacillariophyceae, Centrales) of Lake Como (N. Italy). Journal of Limnology 62, 47-60.

Schmidt, A., Schmidt, M., Fricke, F., Heiden, H., Müller, O., Hustedt, F., 1874-1956: Atlas der Diatomaceenkunde. O. R. Reisland, Aschersleben, Leipzig and Berlin.

Simonsen, R., 1979: The diatom system: Ideas on phylogeny. Bacillaria 2, 9-71.

SMITH, W., 1856: A synopsis of the British Diatomaceae, 2. Van Voorst, London.

SMucKer, N. J., EdLund, M. B., VIS, M. L., 2008: The distribution, morphology, and ecology of a non-native species, Thalassiosira lacustris (Bacillariophyceae), from benthic stream habitats in North America. Nova Hedwigia 87, 201-220.

Stachura-Suchoples, K., Williams, D. M., 2009: Description of Conticribra tricircularis, a new genus and species of Thalassiosirales, with a discussion on its relationship to other continuous cribra species of Thalassiosira Cleve (Bacillariophyta) and its freshwater origin. European Journal of Phycology 44, 477-486.

Szabó, K., KIss, K. T., Ector, L., KecsKés, M., Ács, É., 2004: Benthic diatom flora in a small Hungarian tributary of the River Danube (Rákos-stream). Archiv für Hydrobiologie, Algological Studies 111, 79-94.

Szabó, K., Kiss, K. T., TABA, GY., Ács, É., 2005: Epiphytic diatoms of the Tisza River, Kisköre Reservoir and some oxbows of the Tisza River after the cyanide and heavy metal pollution in 2000. Acta Botanica Croatica 64, 1-46. 
Szemes, G., 1967: Systematisches Verzeichnis der Pflanzenwelt der Donau mit einer zusammenfassenden Erläuterung. In: Liepolt, R. (ed.), Limnologie der Donau 3, 70-131. Schweizer-Bartsche Verlag, Stuttgart.

Theriot, E., Håkansson, H., Kociolek, J. P., Round, F. E., Stoermer, E. F., 1987: Validation of the centric diatom genus name Cyclostephanos. British Phycological Journal 22, 345-347.

Theriot, E., Serieyssol, K., 1994: Phylogenetic systematics as a guide to understanding features and potential characters of the centric diatom family Thalassiosiraceae. Diatom Research 9, 429-450.

Torgan, L. C., Becker, V., BAHI Dos SAntos, C., 2009: Skeletonema potamos (Bacillariophyta) in Patos Lagoon, southern Brazil: Taxonomy and distribution. Revista Peruana de Biología 16, 93-96.

Torgan, L. C., Henriques Vieira, A. A., Giroldo, D., Bahi Dos Santos, C., 2006: Morphological irregularity and small cell size in Thalassiosira duostra maintained in culture. Proceedings 18 International Diatom Symposium, Bristol, 407-416.

Trigueros, J. M., Ansotegui, A., Orive, E., Nó, M. L., 2000: Morphology and distribution of two brackish diatoms (Bacillariophyceae): Cyclotella atomus Hustedt and Thalassiosira guillardii Hasle in the estuary of Urdaibai (northern Spain). Nova Hedwigia 70, 431-450.

TuJi, A., Houki, A., 2004: Taxonomy, ultrastructure and biogeography of Aulacoseira subarctica species complex. Buletin of the National Science Museum, Series B 30, 35-54.

Tuji, A., Williams, D. M., 2006: Type examination of the freshwater centric diatom Aulacoseira pusilla (F.Meister) Tuji et Houki (in Japanese). Diatom 22, 70-73.

Uherkovich, G., 1971: Die Mikrophyten in der Trift des Flusses Theiss (Tisza). Das Phytoseston der Theiss (in Hungarian). Szolnok Megyei Múzeumi Adattár 20-22, 1-282.

VAn Heurck, H., 1882: Synopsis des Diatomées de Belgique. Atlas. Ducaju \& Cie, Anvers.

Van Heurck, H., 1885: Synopsis des Diatomées de Belgique. Texte. Martin Brouwers \& Co., Anvers.

VAn HeurcK, H., 1896: A Treatise on the Diatomaceae. Translated by W.E. Baxter. William Wesley \& Son, London.

WEBER, C. I., 1970: A new freshwater centric diatom Microsiphona potamos gen. et sp. nov. Journal of Phycology 6, 149-153.

WENDKER, S., 1991: Cyclotella hakanssoniae sp. nov. (Bacillariophyceae) - eine kleine Cyclotella-Art aus dem Schlei-Ästuar (BRD). Nova Hedwigia 52, 359-363.

Wojtal, A. Z., Kwandrans J., 2006: Diatoms of the wyzyna Krakowsko-Czestochowska Upland (S Poland) - Coscinodiscophyceae (Thalassiosirophycidae). Polish Botanical Journal 51, 177-207. 